\title{
Enhancing Nationally Determined Contributions: Opportunities for Ocean-Based Climate Action
}

Eliza Northrop, Susan Ruffo, Gwynne Taraska, Lisa Schindler Murray, Emily Pidgeon, Emily Landis, Elizabeth Cerny-Chipman, Anna-Marie Laura, Dorothée Herr, Lisa Suatoni, Gerald Miles, Tim Fitzgerald, Joshua D. McBee, Tamara Thomas, Sarah Cooley, Anne Merwin, Ariane Steinsmeier, Doug Rader, and Mario Finch

\section{Disclaimer}

Working Papers contain preliminary research, analysis, findings, and recommendations. They are circulated to stimulate timely discussion and critical feedback, and to influence ongoing debate on emerging issues. Working papers may eventually be published in another form and their content may be revised.

\section{Suggested Citation}

Northrop, E., S. Ruffo, G. Taraska, L. Schindler Murray, E. Pidgeon, E. Landis, E. Cerny-Chipman, A. Laura, D. Herr, L. Suatoni, G. Miles, T. Fitzgerald, J.D. McBee, T. Thomas, S. Cooley, A. Merwin, A. Steinsmeier, D. Rader, and M. Finch. 2020. “Enhancing Nationally Determined Contributions: Opportunities for Ocean-Based Climate Action" Working Paper. Washington, DC: World Resources Institute. Available online at www.wri.org/publication/enhancing-nationally

-determined-contributions-opportunities-for-ocean-basedclimate-action.

\section{CONTENTS}

Executive Summary.

Introduction

1. Ocean-Based Mitigation Options

2. Ocean-Based Adaptation Options ........ . 20

3. Financing Ocean-Based Climate Action . . . . . 27

Conclusion.

Appendix A

Appendix B

Endnotes 35

References 35

Acknowledgments

\section{CLIMATE} ADVISERS
CONSERVATION INTERNATIONAL

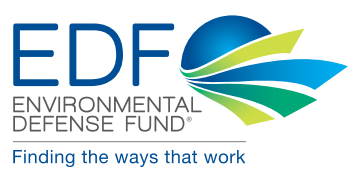

Finding the ways that work

\section{TheNature Conservancy}




\section{Executive Summary}

\section{HIGHLIGHTS}

- Current commitments in Nationally Determined

Contributions (NDCs) are not sufficient to limit global

atmospheric temperature rise to $1.5^{\circ} \mathrm{C}$. Recent reports from the Intergovernmental Panel on Climate Change (IPCC) have made clear that significantly strengthened mitigation efforts are essential.

- A global temperature increase of even $1.5^{\circ} \mathrm{C}$ will have serious consequences for the ocean beyond those already being seen. Stronger action to mitigate greenhouse gas (GHG) emissions is a global imperative that will require an inclusive approach across the whole of the global economy.

- Despite being heavily impacted by climate change, the ocean and ocean economy can also contribute to global efforts to limit warming. The potential of the ocean as a source of opportunities for mitigation is not limited to its natural ecosystems but extends to the ocean economy, including transport, energy, and food production.

- This guide presents a set of options for ocean-based sectoral mitigation targets, policies, or measures for countries to include in new or updated NDCs. It also includes a set of options for ocean-based adaptation measures for those countries that continue to include an adaptation component in their NDCs.

- The opportunities for ocean-based climate action identified in this guide are drawn from four ocean-based subsectors that show the greatest mitigation potential while also delivering significant cobenefits: marine conservation (coastal and marine ecosystem restoration and protection), oceanic and coastal fisheries, marine transport, and oceanbased renewable energy.

- For island and coastal countries, ocean-based mitigation action can help to further increase economy-wide ambitions by providing additional means of reducing emissions or enhancing natural ocean-based sinks.

- Ocean-based climate action must be accompanied by deep cuts in emissions across terrestrial GHG sources, including measures to phase out fossil fuels, create sustainable food systems, and increase carbon sequestration and storage in forests and other natural ecosystems.

\section{CONTEXT}

Increased atmospheric carbon dioxide $\left(\mathrm{CO}_{2}\right)$ and an atmospheric temperature increase of even $1.5^{\circ} \mathrm{C}$ will have serious consequences for the health of the ocean and the communities and economies that rely on it (IPCC 2019). More than 600 million people (approximately 10 percent of the world's population) live in coastal areas that are less than 10 meters above sea level, and nearly 2.4 billion people (or about 40 percent of the world's population) live within 100 kilometers (km) (60 miles) of the coast (UN Sustainable Development Knowledge Platform 2017). More than 3 billion people depend on fish as a primary source of daily protein, and millions more look to the ocean economy as a source of their livelihoods. Even without climate change, the ocean and ocean economy are at risk-critical habitats such as mangroves and coral reefs are disappearing at an alarming rate; over 90 percent of the world's fisheries are overfished or maximally sustainably fished (FAO 2020); and pollution, such as plastic and chemicals, shows no sign of abating. Climate change and acidification resulting from $\mathrm{CO}_{2}$ emissions will only compound this crisis.

\section{It is abundantly clear that stronger action to mitigate GHG emissions is a global imperative that will require an inclusive approach across the whole of the global econ- omy. The Special Reports from the IPCC on Global Warming of $1.5^{\circ} \mathrm{C}$ and the Ocean and Cryosphere in a Changing Climate confirmed that current efforts, as expressed in Nationally Determined Contributions (NDCS), are inadequate (IPCC 2019). To date, much of the attention in the international climate effort has been directed to the role of land-based sources of emis- sions and sinks.}

The ocean and its coastal regions offer a range of currently underutilized opportunities and innovations for countries to consider when enhancing their national climate ambition and actions to ensure the goals of the Paris Agreement are met. In addition to the reductions that must be achieved from land-based economic sectors, oceanbased climate action can play an important role in a country's efforts to decarbonize its economy. Many islands and coastal countries that depend heavily on their marine natural resources have emphasized the importance that ocean-based climate action (both mitigation and adaptation) can play as a strategic consideration in achieving resilient economies, food supply chains, and energy security. 
Including ocean-based sectoral targets, policies, and measures in new or updated NDCs can be used strategically as a clear signal to investors (public and private) to direct global financial flows to accelerate transition of the ocean economy. NDCs can act as roadmaps for domestic and international private and public funding to catalyze holistic investment into actions that will reap both short- and longterm economic, social, and environmental benefits for national economies. Because NDCs encompass countries' short-term mitigation and adaptation priorities, they can be useful tools to promote alignment in investment with national, long-term priorities for the marine environment and land-ocean interface. Such alignment can better facilitate sector-coupling solutions, such as the development of ocean-based renewable energy that also supports the development of zero-emission fuels necessary for decarbonization of marine transport and avoids investment in stranded assets.

\section{ABOUT THIS GUIDE}

This guide presents a suite of ocean-based mitigation and adaptation options for governments to consider in developing new or updated NDCs. The options identified in this guide do not prescribe whether or not a country chooses its NDC as the vehicle for its Adaptation Communication, and can have equal relevance for countries as they consider their adaptation priorities and plans through other national and local adaptation planning processes such as National Adaptation Plans (NAPs). This guide supplements, as a sector module, the overarching guide, Enhancing NDCs: A Guide to Strengthening National Climate Plans by 2020 (Fransen et al. 2019) and will assist countries in enhancing their climate goals with clearer and more tangible ocean-based mitigation and adaptation targets, policies, and measures. NDC enhancement guide sector modules are also available for power, transportation, agriculture and food, forest and land-use, and short-lived climate pollutants.

The guide may also provide relevant insights into options for a sustainable blue recovery ${ }^{1}$ to COVID-19, with a focus on delivering on the Paris Agreement and the 2030 Agenda for Sustainable Development including its Sustainable Development Goals (SDGs).

\section{OPPORTUNITIES FOR ENHANCING NDCS THROUGH OCEAN-BASED CLIMATE ACTION}

The potential of the ocean as a source of opportunities for mitigation is not limited to its natural ecosystems but extends to the ocean economy, including transport, energy, and food production. If protected and well managed, ocean ecosystems, such as mangroves, salt marshes, and seagrasses, have significant sequestration and storage potential. However, the ocean is also a key economic sector with major industries, including marine transport (passenger and deep sea cargo), energy, and fisheries and marine aquaculture, that can take immediate steps with the technology available to significantly reduce their greenhouse gas (GHG) emissions or contribute to the sustainable renewable energy revolution.

This guide identifies opportunities for ocean-based mitigation and adaptation action across four key oceanbased subsectors. The subsectors are marine conservation (restoration and protection of coastal and marine ecosystems), oceanic and coastal fisheries, marine transport, and oceanbased renewable energy.

Each of these subsectors has significant potential to contribute to economy-wide efforts to reduce emissions and improve the resilience of coastal communities and infrastructure. For many island and coastal nations, their ocean economy is their largest economic sector and therefore should be included in all national climate plans and strategies-including NDCs, Adaptation Communications, and long-term low greenhouse gas emission development strategies (Paris Agreement, Article 4, Paragraph 19 [UNFCCC 2015]).

Ocean ecosystems such as fisheries and reefs, pelagic ecosystems, and coastal wetlands can reduce climate risks and improve resilience to the impacts of climate change. These ecosystems can help reduce climate risk and protect lives and livelihoods by providing a buffer to storm surge and limiting erosion in the face of sea-level rise and climate change. They can further reduce climate risks by serving as an informal "social safety net" and contributing to the resilience of local populations in many countries by enhancing food security; providing new economic opportunities through economic diversification; and improving the quality of coastal 
and marine water, with significant economic benefits in local tourism as well as health benefits through reduction of waterborne diseases.

The inclusion of adaptation in NDCs is voluntary. However, the majority of countries (148 out of 196) chose to include adaptation, either in the form of quantified targets or qualified actions and measures, in their first NDCs (WRI 2020). Under the Paris Agreement, countries can continue to communicate national adaptation information in their new or updated NDCs or use alternative vehicles for their Adaptation Communications, pursuant to Article 7 .

\section{OCEAN-BASED MITIGATION OPTIONS}

The guide presents options for the inclusion of ocean-based mitigation targets, policies, and measures in new and updated NDCs in the following ocean-based areas:

1. Protecting, sustainably managing, or restoring coastal and marine ecosystems and accounting for their sequestration and storage capacity in national GHG inventories. Mangroves, salt marshes, and seagrasses (known as "blue carbon ecosystems" are efficient carbon sinks that hold large carbon deposits. Degradation or loss of these ecosystems can release globally significant carbon emissions into the ocean and atmosphere (Pendleton et al. 2012). Countries can include quantitative targets, policies, or measures to protect or restore coastal blue carbon ecosystems in NDCs, as well as account for the ecosystem as a sink, source, or reservoir. For common accounting methodologies, countries should utilize the "2013 Supplement to the 2006 IPCC Guidelines for National Greenhouse Gas Inventories: Wetlands" (Wetlands Supplement), coastal wetlands chapter, for guidance on the methods to incorporate these ecosystems into the national GHG inventories and accounting (IPCC et al. 2014). It has been estimated that between 0.02 to 0.65 gigatons of carbon dioxide equivalent $\left(\mathrm{GtCO}_{2} \mathrm{e}\right) /$ year of $\mathrm{GHG}$ emissions could be sequestered and stored by increasing the protection and restoration of coastal ecosystems (mangroves, salt marshes, and seagrasses), including the avoided emissions from continued degradation of these ecosystems, which is substantial and has the compounded effect of both releasing existing stored emissions and removing the potential for additional sequestration (HoeghGuldberg et al. 2019).
2. Reducing greenhouse gas emissions from oceanic and coastal fisheries. To reduce emissions associated with fisheries, three options are outlined. ${ }^{2}$ First, countries can target fishing-related fuel consumption in their NDCs as part of their transportation GHG targets. Second, countries can focus on reducing emissions from processing, storage, and distribution of fish and fish products as part of an energy GHG target. Third, policy reform and sustainable management that leads to improved fish stocks-such as science-based catch targets, secure tenure, and the elimination of inefficient fuel subsidies-can have mitigation benefits by reducing fishing effort and fuel use (Costello et al. 2016; Barange et al. 2018). Conservative estimates indicate that a reduction of emissions in wild capture fisheries and marine aquaculture (new feeds to replace fish meal and soy-based proteins) could lead to a mitigation potential of $0.097 \mathrm{GtCO}_{2} \mathrm{e} / y e a r$ by 2030 and $0.18 \mathrm{GtCO}_{2} \mathrm{e} /$ year by 2050 (Hoegh-Guldberg et al. 2019).

3. Reducing greenhouse gas emissions from marine transport. Countries can include sectoral emissions reduction targets for domestic marine transport (e.g., transport between ports of the same country including ferries and national fleets such as the navy or fishing fleets) in their NDCs (transportation sector targets) or commit to policies and measures aimed at incentivizing investment in low- or zero-emission vessels by the private sector (domestic or international); establishing the required renewable energy supply chains to ports; and incentivizing zero-emission vessel technology development and deployment (energy targets). Where relevant, countries could also consider the inclusion of marine transport in carbon pricing schemes. It has been estimated that a reduction of emissions in marine transport (both international and domestic) could lead to a mitigation potential of 0.25-0.50 $\mathrm{GtCO}_{2} \mathrm{e} /$ year by 2030 and 0.9-1.8 $\mathrm{GtCO}_{2}$ e/year by 2050 (Hoegh-Guldberg et al. 2019).

4. Increasing well-sited, environmentally responsible ocean-based renewable energy capacity. For many coastal or island countries, ocean-based renewable energy, such as offshore wind (fixed or floating), tidal, current, or floating solar energy technologies, represents the most viable opportunity to significantly expand their renewable energy capacity. Countries can support the acceleration of these technologies by including sectoral targets aimed at ocean-based renewable energy, committing to research and development (R\&D), or including policies aimed at reducing barriers to their deployment in their NDCs. One important component of this approach is the use of inclusive marine 
spatial planning that ensures ocean-based renewable energy does not negatively impact ocean resources, such as fisheries, and builds local support for development that allows it to move forward more quickly. It has been estimated that increasing ocean-based renewable energy could lead to a mitigation potential of 0.18-0.24 $\mathrm{GtCO}_{2} \mathrm{e} /$ year by 2030 (based on coal displacement) or 0.083$0.117 \mathrm{GtCO}_{2} \mathrm{e} /$ year (based on displacement of current generation mix) and 0.76-5.4 $\mathrm{GtCO}_{2}$ e/year by 2050 (based on coal displacement) or 0.35-2.48 $\mathrm{GtCO}_{2}$ e/year (based on displacement of current generation mix) (Hoegh-Guldberg et al. 2019).

\section{OCEAN-BASED}

\section{ADAPTATION OPTIONS}

Recognizing the importance of the ocean to improving the resilience of coastal and island communities, the guide presents options for inclusion of ocean-based adaptation measures in new and updated NDCs in the following areas:

\section{- Fostering ecosystem-based resilience through coastal} and marine ecosystems. Ecosystem-based adaptation is the use of nature-conservation, restoration, and sustainable management of ecosystems and biodiversity-to help people adapt to the impacts of climate change on their communities (Hale et al. 2009). Countries can create climatesmart marine protected areas (MPAs) ${ }^{3}$ or other effective area-based conservation measures (OECMs) (Kroeker et al. 2019; Roberts et al. 2017; IUCN 2017a.) to protect and enhance the resilience of coastal and marine ecosystems. Countries may consider evaluating actions taken to achieve marine biodiversity targets under the Convention on Biological Diversity and integrating those that include or can be modified to include goals or objectives to improve communities' ability to adapt to climate change. Additionally, countries can protect and restore coastal ecosystems to defend coastlines from sea-level rise and storms, while also providing mitigation benefits and supporting food security, for example, by protecting and restoring habitat for fish (Duke et al. 2007), or by protecting mangroves.

- Building the resilience of fisheries. Climate change is significantly impacting global fisheries, affecting patterns of maximum fish productivity, fish stock ranges, the timing of spawning and migration, and species composition (Barange et al. 2018). Countries can promote the resilience of fisheries and fishing communities through efforts such as incorporating climate information into fisheries science and management-including setting climate-appropriate goals and harvest control rules for species and species groups and enacting policies to address shifts in fish distributions; ending overfishing and rebuilding depleted stocks; stopping illegal, unreported, and unregulated fishing; reducing nonfishing pressures on fish stocks; and adopting adaptive, dynamic, and ecosystem-based approaches to management.

- Addressing ocean acidification. Without mitigation, ocean acidification will continue to threaten marine ecosystem integrity, decrease marine harvests, and harm iconic coral and shellfish ecosystems and fisheries. In parallel with efforts to reduce $\mathrm{CO}_{2}$ emissions, countries can pursue intermediate adaptation efforts to lessen the present impacts of acidification, such as reducing other sources of acidification (e.g., nutrient runoff), developing vegetation- and carbonatebased systems of remediation, and helping prepare marine resource-dependent communities for future impacts.

The options outlined in this report are important not only to support efforts to meet the goals of the Paris Agreement. They also offer an array of valuable cobenefits in terms of enhanced human health and well-being. In this regard, they contribute to improving the resilience of coastal communities and infrastructure, expanding jobs and economic opportunities, enhancing biodiversity, and strengthening food security, alongside providing myriad intrinsic cultural value. Many of these wider benefits are synergistic with and will support the achievement of the UN Sustainable Development Goals by 2030 .

The ocean, its coastal regions, and the economic activities they support can be a source of inspiration and innovation in global efforts to reduce warming and respond to the impacts of climate change. However, oceanbased climate action must go hand in hand with deep cuts in emissions across terrestrial GHG sources, including measures to phase out fossil fuels, create sustainable food systems, and increase carbon sequestration and storage in forests and other natural ecosystems.

\section{Introduction}

The ocean and climate are inextricably linked. The impacts of climate change on the ocean are well documented (IPCC 2019) - heat and carbon dioxide $\left(\mathrm{CO}_{2}\right)$ are devastating ocean ecosystems through effects such as ocean warming, deoxygenation, and acidification. These impacts are a reflection, and 
consequence, of the scale of the role the ocean has already played in mitigating the impacts of climate change for the globe, absorbing more than 90 percent of the heat from humancaused global warming and one-third of our carbon emissions since the Industrial Revolution. Efforts to protect the ocean and its vitally important ecosystems cannot be considered in isolation from the ongoing challenge of stabilizing the global climate.

Despite the causal connectivity between oceans and climate, the role of the ocean as both a buffer and potential solution did not feature prominently in climate change decision-making until the launch of the "2013 Supplement to the 2006 IPCC Guidelines for National Greenhouse Gas Inventories: Wetlands" (Wetlands Supplement). ${ }^{4}$ This was followed by global political mobilization through the first Because the Ocean Declaration at the twenty-first session of the Conference of the Parties (COP 21) in December 2015.

Despite this progress, specific targets, policies, and measures related to carbon sources and sinks in the ocean and ocean economy do not feature prominently in the first round of Nationally Determined Contributions (NDCs) or long-term low greenhouse gas (GHG) emission development strategies under the Paris Agreement. Recent analysis increasingly demonstrates the significant untapped potential of ocean-based climate solutions (Hoegh-Guldberg et al. 2019), expanding the opportunities for countries to more holistically and comprehensively integrate ocean-based climate solutions into new or updated NDCs. With the momentum created by Fiji's COP 23 presidency in 2017 and more recently Chile's COP 25 presidency in 2019, which put a spotlight on both the increasing impact of climate change on the health of the ocean and the opportunities presented by the ocean for climate action, countries may consider specific targets, policies, and measures related to carbon sources and sinks in the ocean and to the ocean economy in their new or updated NDCs.

\section{ABOUT NDC ENHANCEIMENT}

The term "NDC enhancement" captures a central tenet of the Paris Agreement for Parties to seek to raise the ambition of NDCs over time, starting with the invitation for countries to communicate new or updated NDCs in 2020 (Fransen et al. 2017). Broadly speaking, NDC enhancement addresses multiple dimensions: mitigation, adaptation, and communication—-taking into account that the objectives and requirements under the Paris Agreement vary across these components (See Figure 1). Ideally, the NDC enhancement process will align NDCs more closely with the goals of the Paris Agreement through the information necessary to facilitate clarity, transparency, and understanding (CTU); maximize benefits of the NDCs for development and resilience; incorporate relevant opportunities to strengthen partnership, resource mobilization, and implementation; improve transparency; and demonstrate national priorities.

On mitigation, countries must identify opportunities to strengthen the ambition of their NDCs, given the very large emissions gap between the current global emissions trajectory and the pathway consistent with achieving the Paris Agreement's goals. The ambition of a country's NDC is strengthened when an enhanced NDC-including its complete set of mitigation targets and actions, and assuming full implementation-results in lower cumulative emissions than the existing NDC. To determine the effect of NDC enhancement on mitigation ambition, the cumulative impact of all changes to the NDC, including the overlap in the effect of such changes with one another, must be considered (Box 1; Fransen et al. 2017). Aside from their effects on ambition, enhancements related to mitigation can also facilitate stronger implementation, if countries commit to specific policies and measures in support of existing targets, including those related to financial flows, coordinated implementation, and greater integration with national development.

NDCs are the primary vehicle for communicating mitigation goals under the Paris Agreement, yet countries may also choose to include adaptation elements in their NDCs. These elements are identified in the decisions in the Katowice Climate Package adopted at the Conference of the Parties (COP) 24 in Katowice, Poland (Decision 4/CMA.1), (UNFCCC 2018). Countries can consider options for enhancing those elements, taking into consideration their objectives of including adaptation in their NDCs as well as the relationship between their NDCs and their Adaptation Communications (whether it forms the whole or part of their Adaptation Communication), and ensuring alignment with national planning processes, namely the National Adaptation Plan (NAP).

The Paris Agreement indicates that NDCs can be a vehicle for the Adaptation Communications called for in Article 7. In this context, Parties continue to retain flexibility in whether and how they choose to include information related to their national adaptation efforts in NDCs, and in how existing content can be enhanced. For those that do choose to include an adaptation component in a new or updated NDC (either as their Adaptation Communication or as part of it), this guide identifies

6 - Enhancing Nationally Determined Contributions: Opportunities for Ocean-Based Climate Action 


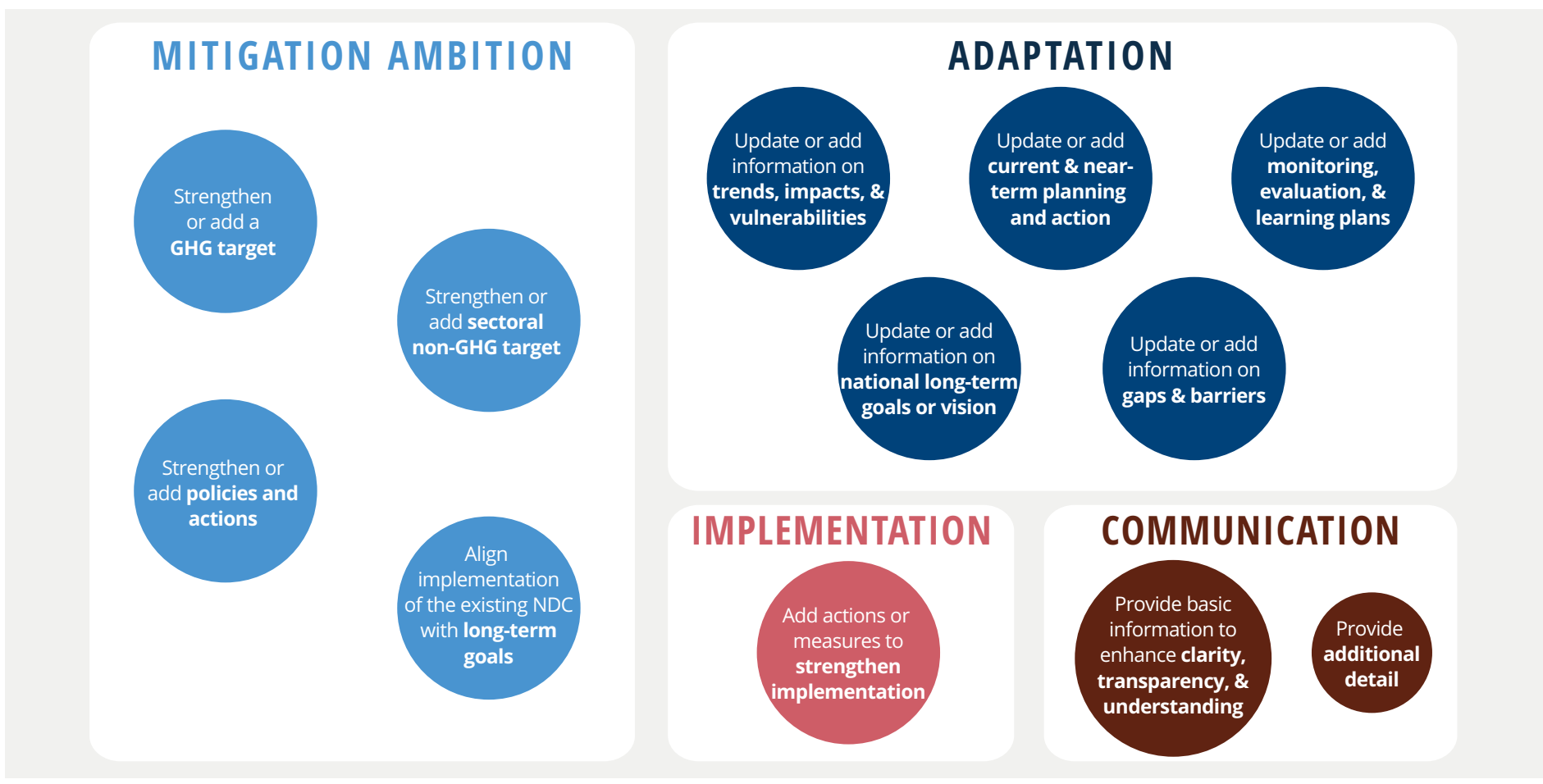

Source: Fransen et al. 2017.

Box 1 | Terms Related to NDC Enhancement

New or updated NDC: From the COP decision adopted together with the Paris Agreement (1/CP.21), these terms refer to the request to Parties concerning NDCs in 2020. A new NDC is one subsequent to the initial NDC when a Party's initial NDC contains a time frame up to 2025. An updated NDC is one communicated by a Party whose initial NDC contains a time frame up to 2030.

Enhanced NDC: In this guidance, a new or updated NDC improves upon the initial NDC with respect to mitigation (ambition and/or implementation), adaptation, and/or communication.

NDC with enhanced mitigation ambition: In this guidance, this term refers to an NDC that, if fully implemented, would result in lower cumulative emissions than the fully implemented existing NDC. It is important to note that a new, updated, or enhanced NDC may not necessarily lead to enhanced mitigation ambition. The baseline for determining this is the complete set of mitigation target(s) and/or action(s) articulated in the original NDC. In determining the effect on mitigation ambition, it is important to consider the cumulative impact of all changes to the NDC, including the extent to which they overlap with each other, as well as the targets, policies, and measures in the existing NDC.

Note: Determining whether a new option will enhance a party's level of ambition can be technically complex. Consider, for example, an NDC that contains both a greenhouse gas (GHG) intensity target (intensity targets specify emission reductions relative to productivity or economic output, for instance, tons of $\mathrm{CO}_{2} /$ US\$, millions of GDP. By contrast, absolute emissions targets specify reductions measured in metric tons, relative only to a historical baseline) and a renewable energy target. Say the GHG intensity target is close to current projections of GHG intensity, but the renewable energy target vastly exceeds current projections of renewable energy capacity. In this case, the renewable energy target is the key driver of ambition, and raising it will likely enhance overall ambition. Conversely, if the GHG intensity target is more aggressive and the renewable energy target less aggressive relative to current projections, raising the renewable energy target may not raise the overall level of ambition. "GHG Protocol: Mitigation Goal Standard" (Levin et al. 2014) and "GHG Protocol: Policy and Action Standard" (Rich et al. 2014) guide GHG accounting that can inform analysis of ambition.

Source: Fransen et al. 2019. 
potential options for ocean-based national adaptation priorities, strategies, policies, plans, goals, and actions (as an element in decision 9/CMA.1). Ultimately, however, the design and content of the adaptation component in an NDC (including information communicated on loss and damage), and how it is enhanced through new or updated NDCs, should reflect a country's rationale for using the NDC to communicate adaptation information. Ultimately the implementation of the priorities, policies, and measures included in an NDC adaptation component should be in alignment with the country's National Adaptation Plan. In this regard, inclusion of ocean-based actions in NDCs could be used to strengthen the ability to integrate the ocean into national climate policies, strategies, and implementation plans as well as to reduce the reporting burden (as referred to in Article 7.10 of the Paris Agreement).

Finally, enhanced communication is essential "to build mutual trust and confidence and to promote effective implementation" (UNFCCC 2015). In enhancing NDCs, improved comparability and consistency across information types is important, and thus, countries are required to include information necessary for clarity, transparency, and understanding (ICTU) in their second and subsequent NDCs.

These elements of NDC enhancement are neither mutually exclusive nor interchangeable. It may be appropriate for a country to enhance its NDC across more than one of these dimensions.

\section{ENHANCING NDCS WITH OCEAN-BASED CLIMATE ACTION MITIGATION}

For island and coastal countries, ocean-based mitigation action can help to further increase economy-wide ambition by providing additional means of reducing emissions (through decarbonizing ocean-based industries or switching to ocean-based renewable energy) or enhancing natural ocean-based sinks.

This guide provides options for including mitigation-based targets, policies, and measures aimed at pursuing the following:

1. Protecting, sustainably managing, or restoring coastal "blue carbon ecosystems" and accounting for their sequestration and storage capacity in national GHG inventories using the IPCC's Wetlands Supplement;

2. Reducing greenhouse gas emissions from oceanic and coastal fisheries;
3. Reducing greenhouse gas emissions from marine transport; and

4. Increasing well-sited, environmentally responsible oceanbased renewable energy.

\section{ADAPTATION}

The options identified in this guide do not prescribe whether or not a country chooses its NDC as the vehicle for its Adaptation Communication and can have equal relevance for countries as they consider their adaptation priorities and plans through other national and local adaptation planning processes, such as NAPs.

This guide provides options for goals, priorities, strategies, policies, plans, and actions (elements of an Adaptation Communication pursuant to decision 4/CMA.1) aimed at pursuing the following:

1. Fostering ecosystem-based coastal resilience through coastal and marine ecosystems;

2. Building the resilience of fisheries; and

3. Reducing the impact of ocean acidification.

The extent of coverage of ocean-based mitigation options and adaptation priorities in the first round of NDCs is outlined in Box 2 and examples are provided in Figure 2 below.

Some countries have already submitted new or updated NDCS that include new targets, policies, and measures for oceanbased climate action or that strengthen existing targets, policies, and measures in their first NDC.

These include the following:

- Chile - Protect at least 10 percent of the Exclusive Economic Zone $(E E Z)^{6}$ in underrepresented eco-regions; by 2025 , protect 20 coastal wetlands; by 2030, protect 10 additional coastal wetlands (Government of Chile 2020).

- Japan - Switch to energy efficiency and energy conservation fishing vessels (Government of Japan 2020).

- Viet Nam - Increase forest coverage, including coastal protection mangrove forest plantation areas, to 42.0-42.5 percent (Government of Viet Nam 2020). 
A majority of countries included references to the ocean or coast in their first round of NDCs (Gallo et al. 2017). ${ }^{\text {Yet }}$ only a small number included specific ocean-based mitigation targets, policies, and measures. For example, although 151 countries have coastal blue carbon ecosystems, only 28 included mitigation related to these ecosystems in their NDCs up to 2016 (Herr and Landis 2016). Close to 60 countries made mention of fisheries in their NDCs; however, only a handful included specific mitigation or adaptation actions. Targets, policies, and measures aimed at marine transport and ocean-based renewable energy have appeared in fewer than 20 NDCs. Examples include the Marshall Islands, which explicitly sets a target of reducing GHG emissions from domestic shipping, and Fiji, which referenced the need for further research and development for ocean and wave energy to reduce the use of fossil fuels (see Figure 2).

This gap indicates an opportunity for coastal and island countries to increase their climate ambition through ocean-based mitigation options in their new or updated NDCs.

Source: Authors.

Figure 2 | Examples of Ocean-Based Targets and Measures in the First Round of NDCs

\section{BELIZE}

Aims to achieve, among interventions under the fisheries sector, the sustainable management of the fisheries resources, and the conservation and preservation of fisheries resources and marine habitats in promoting reef ecosystem resilience (Government of Belize 2015).

\section{HAITI}

Sets conditional targets to protect the country's marine protected areas (MPAs) and conserve and expand existing mangrove forests by 19,500 hectares (ha) by 2030 . Sets as unconditional targets to protect MPAs in the south coast of Haiti and conserve and expand existing mangrove forests by 10,000 ha by 2030 (Government of Haiti 2015).

\section{REPUBLIC OF MARSHALL ISLANDS}

Reduce GHG emissions from domestic ocean-based transport by 2.3 megatons/cubic meters (MtM ${ }^{3}$ ) by 2030 through sea efficiency improvements. The use of new technologies for the extraction of ocean energy may be explored as a possible means of achieving additional GHG reductions (Government of the Republic of Marshall Islands 2015).

\section{FIJI}

Reduce dependence on imported fossil fuel for electricity generation by continued research and development (R\&D) of new renewable energy technologies such as ocean and wave energy (Government of Fiji 2015).

\section{VIET NAM}

Increase the forested coastal areas to 380,000 ha, which includes the planting of 20,000 to 50,000 ha of additional mangrove trees (Government of Viet Nam 2015).

\section{SRI LANKA}

Create green belt zones along the coastline and establish 1,000 ha of coastal forests on the island (Government of Sri Lanka 2015).

\section{MADAGASCAR}

Reinforce natural protection and reduce vulnerability of coastal, inshore, and marine areas affected by coastal erosion and shoreline recession (Government of Madagascar 2015).

\section{AUSTRALIA}

Intends to include reductions from mangroves, seagrasses, and other coastal blue carbon ecosystems in its NDC using the IPCC Wetlands Supplement report (Government of Australia 2015).

\section{THE KINGDOM OF TONGA}

Improve resilience by doubling the 2015 number of marine protected areas by 2030 (Government of the Kingdom of Tonga 2015). 


\section{ABOUT THIS GUIDE}

This guide on ocean-based opportunities for NDC enhancement is one module in a broader series of guidance documents on NDC enhancement developed by World Resources Institute (WRI) and the United Nations Development Programme (UNDP) (Figure 3). The series includes a general (not sector-specific) guide, Enhancing NDCs: A Guide to Strengthening National Climate Plans by 2020 (Fransen et al. 2019) as well as additional guidance on individual sectors and themes, including power, transportation, agriculture and food, forests, and short-lived climate pollutants.

The use of this guidance is entirely voluntary; countries are free to use it in whole or in part and to adapt it to their national circumstances, as relevant. The guidance is intended to complement, but not substitute for, NDC provisions in the Paris Agreement and the Katowice Rulebook (UNFCCC 2018).

This guide is organized as follows: Section 1 discusses the mitigation opportunities in ocean ecosystems and ocean economic subsectors; Section 2 discusses the relevance of the ocean for resilience and improving the adaptative capacity of communities and industry in the face of climate impacts; and Section 3 looks at innovative financing options for ocean-based climate action.
A summary of additional guidance relevant to the identification and development of ocean-based climate action is contained in Appendix A.

\section{Ocean-Based Mitigation Options}

The rationale for enhancing the mitigation ambition of Nationally Determined Contributions sooner rather than later is threefold: the window for climate stability is closing; countries have a growing number of opportunities to enhance their ambition; and countries that act ambitiously can benefit from early action (Fransen et al. 2019)

Following the findings of the IPCC Special Report on the implications of $1.5^{\circ} \mathrm{C}$ warming above the preindustrial period (IPCC 2018), it is now abundantly clear that stronger action to mitigate greenhouse gas (GHG) emissions is a global imperative that will require an inclusive approach across the whole of the global economy. To date, much of the attention has been directed toward the role of terrestrial sources of emissions and sinks. The ocean and its coastal regions, however, offer a wide array of additional potential mitigation options.
DESIGNING (I)NDCS IMPLEMENTING NDCS
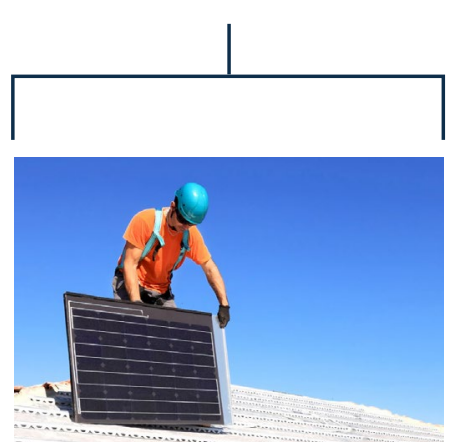

DESIGNING AND PREPARING

INTENDED NATIONALLY DETERMINED

CONTRIBUTIONS (INDCS)

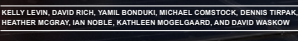

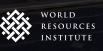

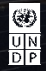
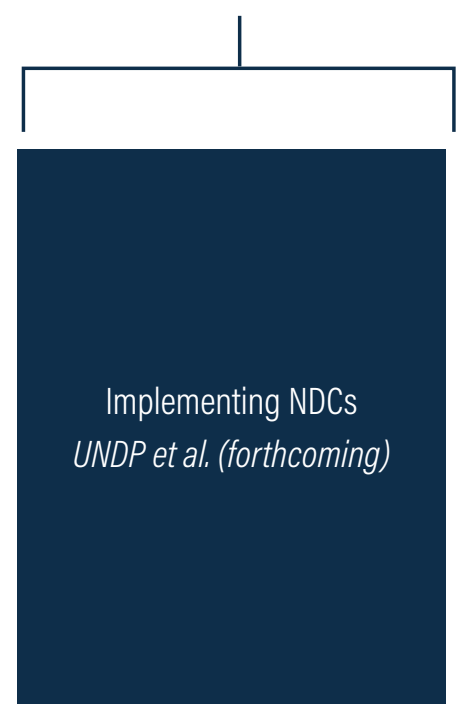

ENHANCING NDCS
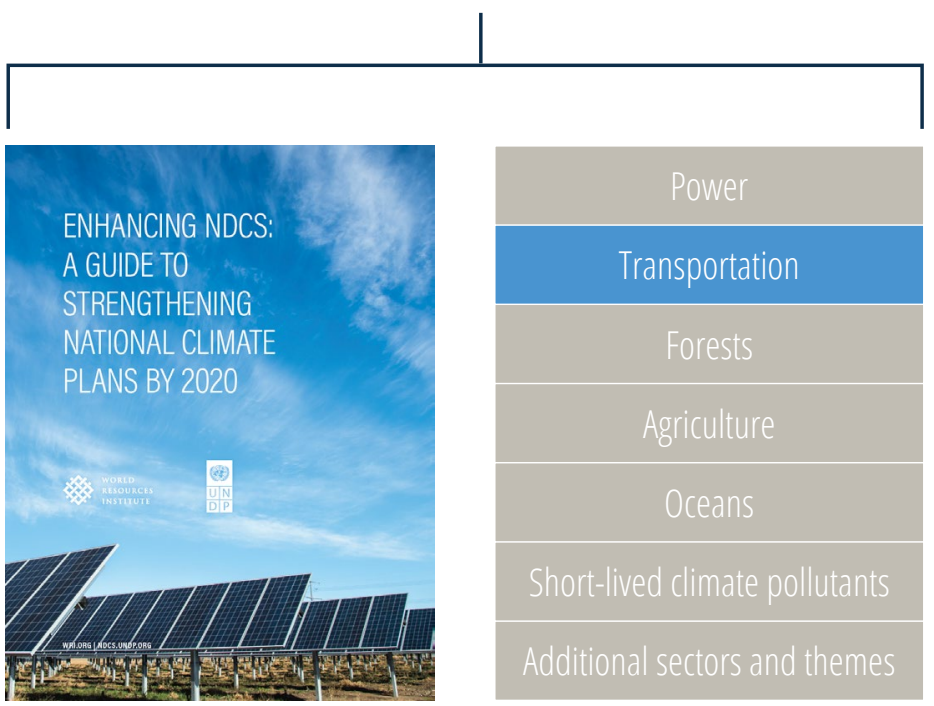

Note: NDCs = Nationally Determined Contributions; INDCs = Intended Nationally Determined Contributions. Source: Fransen et al. 2019. 
Ocean-based mitigation options to reduce or sequester and store emissions offer significant potential to contribute to global efforts to limit global warming and achieve the goals of the Paris Agreement. Recent analysis has found that ocean-based mitigation options could reduce global greenhouse gas emissions by nearly 4 billion tonnes of carbon dioxide equivalent $\left(\mathrm{CO}_{2} \mathrm{e}\right)$ per annum in 2030 and by more than 11 billion tonnes per annum in 2050, relative to projected business-as-usual (BAU) emissions (Hoegh-Guldberg et al. 2019).

\section{COASTAL AND IMARINE ECOSYSTEIMS}

Coastal and marine ecosystems include mangroves, tidal salt marshes, seagrass meadows, reefs (coral or shellfish), seaweed, and kelp forests. Of these ecosystems, mangroves, tidal salt marshes, and seagrass meadows are known as "blue carbon ecosystems" for their ability to sequester and store large quantities of carbon in both the plants and the sediment below (Holsman et al. 2017). Blue carbon ecosystems, although unevenly distributed, are found on every continent except Antarctica. In contrast to terrestrial systems, the most significant carbon pool is stored in the soil of these coastal ecosystems (50-90 percent of the total carbon sequestered). Carbon in the plant biomass is stored for years to decades, whereas carbon in the soil can remain sequestered for millennia if the roots and plants remain intact and healthy. For example, mangrove forests are very efficient on a per-area basis, storing three to five times more carbon per hectare than terrestrial forests.

Despite their proven importance for ocean health and human well-being, mangroves, tidal salt marshes, and seagrasses are being lost at a rate of up to 7 percent per year, varying with location (Table 1). Drivers of ecosystem degradation include, but are not limited to, coastal development and infrastructure, aquaculture cultivation, and destructive fishing practices.

When these coastal ecosystems are degraded or destroyed, they not only lose their long-term potential to sequester and store more carbon, but in fact produce greenhouse gases, emitting the carbon they have stored for centuries into the ocean and atmosphere. Even partially degraded systems can release stored carbon and other greenhouse gases unless effective management systems are in place. Many coastal wetlands have been altered fundamentally by ditching and draining that changes their hydrology and salinity patterns, which in
Table 1 I Global Extent and Loss Rates of Blue
Carbon Ecosystems

\begin{tabular}{|l|l|l|}
\hline ECOSYSTEM & $\begin{array}{l}\text { AREA COVER } \\
\left.\mathbf{( K M}^{\mathbf{2}}\right)\end{array}$ & $\begin{array}{l}\text { RECENT RATES OF LOSS } \\
\text { (\%/YEAR) }\end{array}$ \\
\hline Mangroves & 138,000 & 0.11 \\
\hline Salt marshes & 55,000 & $1-2$ \\
\hline Seagrasses & 325,000 & $2-7$ \\
\hline Seaweeds & $3,540,000$ & Not known
\end{tabular}

Source: Hoegh-Guldberg et al. 2019.

turn alters biogeochemical cycles and greenhouse gas fluxes. Emissions include a mixture of carbon dioxide, methane, and even nitrous oxide, when the underlying groundwater is already nitrate enriched, as is often the case. Thus, water management is often necessary to maintain conditions that minimize GHG emissions. Altered salinity induced by sea-level rise and intensifying storms can exacerbate these risks as well.

There is often confusion around the ability to incorporate these ecosystems into national inventories; however, the "2013 Supplement to the 2006 IPCC Guidelines for National Greenhouse Gas Inventories: Wetlands" (Wetlands Supplement) provides detailed guidance and methodologies in a tiered approach to account for coastal wetlands-mangroves, tidal salt marshes, and seagrasses (blue carbon ecosystems) _-in a national GHG inventory based on technical capacity and type of data available (see Box 3 for a more detailed overview of how the Wetlands Supplement can be applied and where countries can access the necessary data to support the inclusion of blue carbon ecosystems in NDCs).

Other coastal and marine ecosystems, such as kelp forests, could have mitigation potential but require further scientific consensus on the sequestration potential and uncertainty of carbon storage and flow before they can be included in NDCs (even as policies and actions or non-GHG targets). Therefore, this guide does not provide options for the inclusion of coastal and marine ecosystems beyond mangroves, salt marshes, and seagrasses for their quantifiable mitigation potential in NDCs but does describe the vast adaptation benefits in the following sections. 
For blue carbon ecosystems to be appropriately incorporated into NDCs, governments should ensure that to facilitate clarity, transparency, and understanding (CTU) of mitigation contributions, the following information is included in the NDC (ideally in the CTU section of the NDC):

- Carbon sequestration and storage (including the quantity of carbon removed from the atmosphere or ocean by the ecosystem, emissions resulting from degradation or conversion of the ecosystem, or emissions avoided by conservation of the ecosystem at a national scale, using the IPCC Wetlands Supplement as guidance) is accounted for within the National GHG Inventory, referenced in the National Inventory Report (NIR), or otherwise accounted for in the Biennial Transparency Report/Biennial Update Report. For countries that might currently lack the technical capacity for in-house accounting, inclusion of existing efforts in the NIR can also demonstrate progress (see Box 3).

- Assumptions are well articulated to ensure a clear rationale for the selected methodological approach to calculate anthropogenic drivers affecting carbon storage and estimate emissions and removals.
- Relevant information is provided on management of blue carbon ecosystems (to the extent that such management results in increased or maintained sequestration or emissions reductions).

- Adaptation cobenefits are described when coastal ecosystems are sustainably managed to align with other positive environmental and social impacts and linkages with international frameworks such as the Sustainable Development Goals (SDGs) and Post-2020 Global Biodiversity Framework.

Specific options for including the protection or restoration of blue carbon ecosystems in the mitigation component of NDCS are contained in Table 2 . Additional details regarding guidance on incorporating blue carbon into NDCs can be found in "Blue Carbon and Nationally Determined Contributions: Guidelines on Enhanced Action" (The Blue Carbon Initiative 2020).

\section{Box 3 | Options for Including Blue Carbon Ecosystems in National GHG Inventories and Biennial Transparency Reports under the Paris Agreement}

All countries are encouraged to use the latest IPCC guidance to develop their National GHG Inventories and Biennial Transparency Reports (BTRs) under the Paris Agreement beginning in 2024. The latest IPCC-approved methodologies include information on the mitigation potential of blue carbon ecosystems as detailed in the IPCC Wetlands Supplement. The supplement provides a tiered approach to accounting for blue carbon ecosystems, which allows countries to incorporate this carbon pool in a stepwise approach based on national circumstances and capacity and thus allows for improvements over time. The inclusion of blue carbon ecosystems in the land use, land-use change, and forestry (LULUCF) section of the National GHG Inventory is key to be able to account for these ecosystems in an NDC's mitigation component. The common reporting tables used for BTRs can enable mangroves to be represented as either forests or wetlands within the LULUCF category, whereas seagrasses and tidal salt marshes can only be accounted for under wetlands. Based on the IPCC Wetlands Supplement's mean emission factor value (2 tonnes of carbon per hectare per year [tC/ha/year]) for organic wetlands soils after drainage, as much as an estimated 1.02 billion tonnes of $\mathrm{CO}_{2}$ are being released annually from degraded coastal blue carbon ecosystems (mangroves, tidal marshes, and seagrasses).

Inclusion in Tier 1 greenhouse gas inventories requires only an understanding of the change in distribution of mangroves in the country, with default values assigned to the carbon stocks. As a result, datasets on distribution change provide an opportunity for countries without their own remote sensing abilities to use big datasets like Global Mangrove Watch (see Appendix B) to include mangroves in their GHG inventory. Additionally, country-level data on biomass and soil carbon allow countries to begin the process of a Tier 2 inventory, which requires country-specific land-use data and can help inform national-level decisions on reducing LULUCF emissions from blue carbon ecosystems and enhancing carbon stocks. Some of these data are already available for many countries for aboveground biomass and soil (see Appendix B).

Detailed guidance on implementing the IPCC Wetlands Supplement is available. See Appendix B for detailed summaries on available and upcoming data on mangroves that can be used to meet the accounting and reporting guidelines under the IPCC.

Source: Authors.

12 • Enhancing Nationally Determined Contributions: Opportunities for Ocean-Based Climate Action 


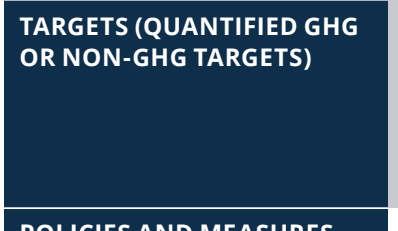

POLICIES AND MEASURES
- Expand and increase the ambition of existing economy-wide GHG targets to include blue carbon ecosystems.

- Expand existing sectoral LULUCF GHG reduction targets to include blue carbon ecosystems.

- Define specific GHG reduction targets for blue carbon ecosystems.

- Define or strengthen area-based non-GHG targets for restoration or protection of blue carbon ecosystems.

- Commit to specific improvements in accounting capacity to support inclusion of blue carbon in NDCs and associated national climate plans and strategies, such as additional national data collection, science, and technical capacity.

- Commit to reforming fiscal policies to invest in and incentivize restoration and protection of blue carbon ecosystems.

- Commit to incentives that reduce the pressure of exploitation of coastal ecosystems and ecosystems with high commercial values (i.e., reduce the opportunity costs of conservation and restoration).

- Commit to improved management of blue carbon ecosystems by establishing inshore buffer zones to reduce impacts from adjacent land use and allow blue carbon ecosystems to migrate in response to sea-level rise.

Source: Authors.

\section{OCEANIC AND COASTAL FISHERIES}

Food production is responsible for a quarter of anthropogenic greenhouse gas emissions globally; however, fisheries are typically excluded from global GHG assessments. Analysis reveals that in 2011, fisheries generated at least 179 million tonnes of greenhouse gas emissions, equivalent to the emissions of approximately 38 million vehicles or 4 percent of emissions from the global food production system (Parker et al. 2018). ${ }^{7}$ The main source of emissions from the fisheries sector is the use of fossil fuel in fishing vessels. However, refrigeration, waste, and transport (particularly air transport) can also be significant contributors, depending on how the processing of catch and the supply chain are managed.

Including fishing-related emissions reduction as a stand-alone sectoral target in NDCs, or ensuring its inclusion in transport sector targets, is a clear opportunity to enhance mitigation ambition (Barange et al. 2018).

Options for reducing emissions from fishing vessels through design and operation include the following:

- Changing the hull shape, updating to more efficient engines and equipment, and reducing vessel speed could reduce vessel emissions between 10 and 30 percent (Barange et al. 2018).
- Converting vessels and/or requiring new vessels to utilize hybrid engines and renewable energy can also significantly reduce vessel emissions (Manouchehrinia 2018).

- Providing fishers with a fuel consumption meter can reduce fuel use (van Marlen 2009).

- Improving technology, given that for certain gear types, the gear itself can be a considerable source of energy use (e.g., trawls and dredges). In these cases, small improvements in technology can yield large benefits. For example, modifying otter boards in trawls in the Gulf of Mexico shrimp fishery by switching from wooden boards to curved steel boards of a smaller size reduced fuel use by 28 percent (Haby and Graham, n.d., as cited in Barange et al. 2018).

- Managing efforts in ways that reduce overcapacity of fishing fleets can also increase efficiency. For example, many countries are adopting secure tenure approaches in their domestic fisheries, which can improve their sustainability and create the governance and enabling environment to manage effort among fishers if implemented appropriately (Gutiérrez et al. 2011; Melnychuk et al. 2012; Box et al. 2018). 
- Lastly, removing harmful fisheries subsidies that enable otherwise unprofitable long-distance fishing can also dramatically reduce fuel consumption across the sector.

Improvements in efficiency could have the unintended impact of increasing fishing by augmenting fishing capacity (Greer et al. 2019), so it is important that changes are implemented in the context of an effective fisheries management framework that restricts catch to sustainable levels and is based on an understanding of the local context and fleet dynamics.

Beyond changes to vessel design and operation in wild-capture fisheries, emissions reduction efforts can also focus on downstream seafood processing, storage, and distribution. For example, reliance on temperature control and long-distance travel increases demand for refrigerants and energy in some fisheries, which could be reduced through improvements in transportation and cooling efficiency and changes to supply chains and consumer preferences. Shoreside processing and storage facilities have more immediate potential than vessels to use renewable energy in their operations, along with efficiency improvements related to cold storage and ice production (Barange et al. 2018). And while long supply chains are an artifact of the global seafood market, there may exist emissions reduction opportunities at each step that lessen the carbon footprint of seafood production, transport, and consumption while still ensuring local jobs and economic opportunities. ${ }^{8}$ Not only will such measures reduce GHG emissions by improving energy efficiency, but they can also decrease loss and waste in the seafood supply chain, both in terms of harvesting seafood and postharvest processing (Springmann et al. 2018). More than one-third (by weight) of all food that is produced is currently lost in the supply chain (Gustavsson et al. 2011), and even higher fractions may be lost in some seafood supply chains (Love et al. 2015). Food loss and waste is responsible for approximately 6 percent of total global greenhouse gas emissions (Poore and Nemecek 2018).

Actions to protect and increase fish stocks and sustainably manage fisheries can also support mitigation while providing broader benefits (Barange et al. 2018; Parker et al. 2015). Rebuilding fish stocks to healthy biomass levels can make it easier to catch fish, which can reduce fossil fuel consumption during fishing and improve efficiency per pound landed (Ziegler and Hornborg 2014). Strengthening fisheries management and rebuilding fish populations can reduce fuel consumption by up to 80 percent while also increasing catch per unit effort (Parker et al. 2018). There are many ways to achieve increased stock biomass; the best management approaches will depend on the fishery and the local socio-ecological system. Restoring coastal ecosystems, such as mangroves and seagrasses (addressed in the previous section on blue carbon), can often yield improved carbon storage capability while protecting nursery habitats for fish stocks in what could be considered a win-win scenario. In small-scale fisheries in Indonesia and the Philippines, for example, improved governance in coastal fisheries and establishment of well-designed fisheries reserves has resulted on average in a doubling of the biomass of target species within the fisheries (Box et al. 2018).

In terms of marine (i.e., finfish and crustacean) aquaculture, the largest source of emissions is commonly from production of the feed (Henriksson et al. 2012; Parker et al. 2018; Pelletier et al. 2009; Pelletier and Tyedmers 2010; Robb et al. 2017). Increasingly, research is being directed toward the identification of suitable low-carbon feed sources. Some of the most promising options are a variety of protein concentrates derived from a range of single-cell organisms including yeast, bacteria, or microalgae (Sarker et al. 2018). Also promising are mealworms and other insects that have been grown on food scraps (therefore having the double effect of also reducing emissions from food waste) (Bulak et al. 2020). Investing in additional R\&D to support such efforts would help drive a reduction in the emissions profile of aquaculture feeds that represent a substantial source of future emissions reductions, or at least avoidance of emissions increases as marine aquaculture expands to respond to future population growth and demand for additional seafood.

For successful implementation of any of the options discussed above, the active engagement of fishers and their communities in the design and development of new practices is essential so as to preclude negative impacts on the role fisheries play in community food security and livelihoods and to ensure the measures are ultimately successful in achieving their full mitigation potential.

Specific options for including the oceanic and coastal fisheries in the mitigation component of NDCs are listed in Table 3. 
Table 3 | Options for Incorporating Targets, Policies, and Measures for Oceanic and Coastal Fisheries into New or Updated NDCs

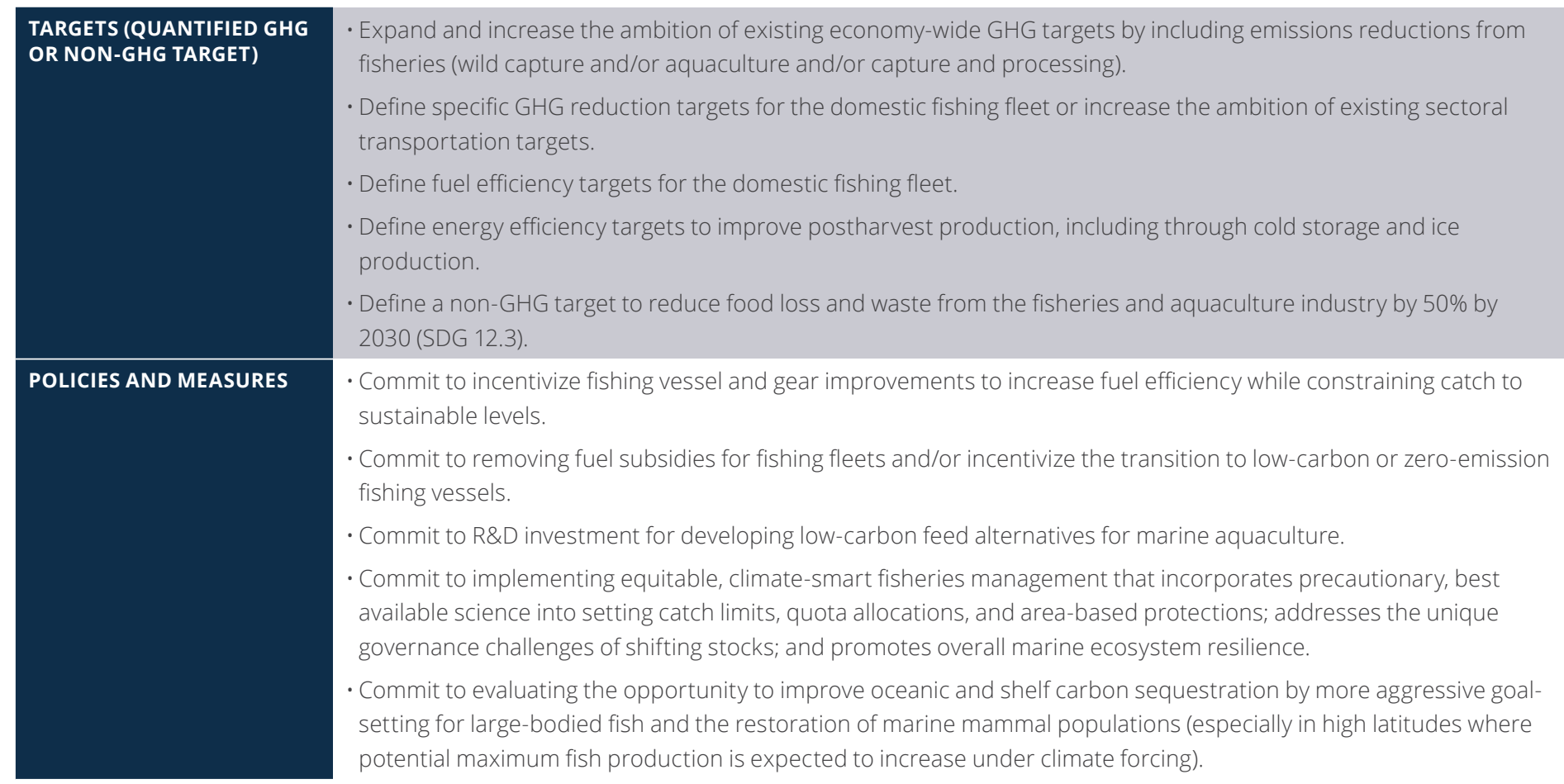

Source: Authors.

\section{MARINE TRANSPORT}

Phasing out emissions from marine transport, including international ${ }^{9}$ and domestic transport, ${ }^{10}$ is necessary to support the goals of the Paris Agreement. Not only is marine transport a significant source of global emissions, but there are identifiable pathways to reduce GHG emissions. Marine transportation has the potential for roughly 100 percent reduction in operational net GHG emissions by changing how vessels store and consume energy on board. For short voyages, batteries could be used to store electricity; for longer or deep-sea voyages, low- or zero-emission synthetic or "e" fuels will be needed to replace fossil fuels (e.g., renewable hydrogen, hydrogen-based fuels such as ammonia, and fuels that have been post-processed with $\mathrm{CO}_{2}$ to make hydrocarbons). Successfully decarbonizing marine transport will be largely determined by the timescales needed to renew or retrofit the existing fleet and develop the infrastructure to use and supply these new energy sources. Having zero-emission vessels commercially available by 2030 will be crucial in meeting the goals of the Paris Agreement-making the inclusion of sector-specific targets, policies, and measures in new and updated NDCs necessary for this sector.

The International Maritime Organization (IMO) is the international body that focuses on international shipping emissions, but countries can include enabling targets within their NDCS that focus on reducing emissions from domestic shipping and passenger transport that are not covered by the IMO, as well as policies and measures that would support or incentivize the shipping industry to transition the international fleet (Murphy 2018). The IMO's Fourth GHG Study, released in August 2020, revealed that domestic shipping GHG emissions have been underestimated. The share of total shipping emissions that falls within domestic shipping and therefore national jurisdictions is 
now estimated to be approximately 30 percent-total shipping emissions now exceed 1 gigaton of carbon dioxide equivalent $\left(\mathrm{GtCO}_{2} \mathrm{e}\right)$ per annum and are projected to rise to between 1 and $1.45 \mathrm{GtCO}_{2}$ e per annum by 2050.

Domestic shipping and passenger transport offers significant opportunities for enhanced mitigation ambition. Progress in new technologies to reduce emissions from coastal passenger transport, for example, also offers cobenefits for local air quality and noise reduction. Norway, Scotland, and Sweden, for example, are innovating with ferry fleets powered by wind energy or batteries charged by renewable sources. Such innovation and technology could support capacity-building and skill-sharing with coastal or small-island developing countries that rely on ferries for transporting people and goods.

The sector's move away from oil to low- or zero-emission fuels (e.g., hydrogen) can be significantly accelerated by government action starting with domestic fleets and creating supportive national enabling environments to support the industry's transition (Barbosa 2020). Examples of recent domestic target setting are highlighted in Box 4 below.
Reducing emissions from domestic vessels can also provide a powerful signal to the private sector, spurring technological innovation and the land-side renewable energy and fuel supply chain transition that will be a prerequisite to deep-sea zeroemission vessels. Danish shipping company Maersk announced in December 2018, for example, that it would be carbon-neutral by 2050 and have commercially viable carbon-neutral vessels by 2030 (Maersk 2018). Banks representing 20 percent of the US\$450 billion global shipping industry recently pledged to limit lending to shipping companies that do not align with strict GHG reduction goals (Poseidon Principles n.d). Such action from the private sector has increased calls for greater government action through policy coordination and creation of an enabling environment to support the industry in this transformation.

Specific options for including marine transport in the mitigation component of NDCs are listed in Table 4.

\section{Box 4 | Recent Domestic Shipping Initiatives}

Norway has released a new national action plan for green shipping, which sets emissions targets, policies, and actions. The plan commits Norway to a 50 percent reduction of greenhouse gas emissions from domestic shipping and fishing compared to 2005 levels by 2030 (Norway, Ministry of Climate and Environment 2019).

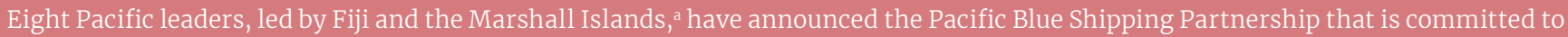
reducing the use of fossil fuels in domestic shipping by 40 percent by 2030 with a view to a 100 percent carbon-free marine transport sector by 2050 (MCST 2020). This ambition will be achieved through a 10-year program of large-scale investment in retrofitting and vessel replacement. The sector currently faces a range of challenges including the prevalence of old, inefficient, and undermaintained vessels, and a lack of supporting modern infrastructure including ports and facilities for bunkering, shipbuilding, maintenance, and repair. Sea transport within and between Pacific Island nations is the most expensive per unit distance and per capita in the world with fuel representing 40-60 percent of a ship's operating costs (Holland et al. 2014). Transportation and mobility are cross-cutting issues central to the sustainable development of the Pacific. Through implementing the Pacific Blue Shipping Partnership, the vision is to reduce global emissions and improve the mobility, safety, and resilience of Pacific Island communities.

Domestic targets such as these are suitable for reflection in new or updated NDCs (either as stand alone sectoral targets or enabling a more ambitious economy wide target) (see Table 3).

Note: a Other nations include Kiribati, Samoa, Solomon Islands, Tonga, Tuvalu, and Vanuatu. Source: Authors. 
Table 4 | Options for Incorporating Targets, Policies, and Measures for Marine Transport in New or Updated NDCs

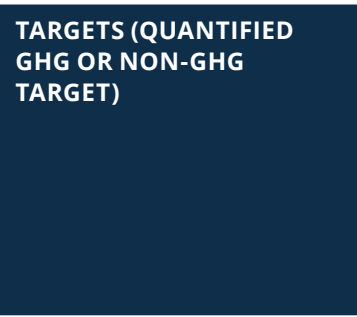

POLICIES AND MEASURES
- Expand and increase the ambition of existing economy-wide GHG targets by including emissions reductions from domestic marine transport.

- Expand and increase the ambition of sectoral transport GHG targets by including emissions reductions from domestic marine transport.

- Define a specific GHG target for domestic shipping and/or domestic fleets.

- Define a non-GHG target to phase out GHG emissions from coastal passenger transport by 2030 through technology transfer and R\&D in battery- and wind-powered ferries.

- Commit to developing cross-sectoral decarbonization plans that link strategies to transition land-based energy sources and supply chains with ports and marine fleets.

- Commit to creating incentives for zero-emission vessels through ports; for example, reduce administrative burdens on port entry, operation, and release for early adopters of zero-carbon solutions.

- Commit to developing long-term plans and strategies to avoid potential fuel supply lag and incentivize large-scale domestic production or import of zero-emission fuels.

- Commit to working with port authorities to support port entry, operation, and release discounts for zero-emission vessels in accordance with Maritime Environment Protection Committee (MEPC) Port Resolution 74/7/10.

- Commit to designating part of the domestic fleet (e.g., fishing fleets, navy, passenger transport) to foster opportunities for zero-carbon technology development and its testing and application.

- Commit to mandating transparent reporting of climate risk in domestic fleet investments.

- Commit to financing technology transfer and R\&D for the transition to zero-emission passenger and freight transport.

- Commit to investing in R\&D on how to diminish carbon emissions in the entire shipping industry activity chain, from shipyard and fuel production to shipbreaking

Source: Authors.

\section{OCEAN-BASED RENEWABLE ENERGY}

A significant expansion of renewable energy capacity is essential to meet the goals of the Paris Agreement and to achieve netzero emissions by $2050 .{ }^{11}$ For many countries, this can include an expansion of well-sited ocean-based renewable energy, notably fixed or floating offshore wind installations (current capacity remains predominantly fixed, but further investment into R\&D for floating turbines will improve commercial viability, particularly in markets with already high renewable energy penetration). In addition to wind, there are many other marine energy technologies under development, including wave energy technologies, tidal and ocean current energy technologies, osmotic or salinity gradient technologies, and ocean thermal energy converters.
Significant expansion of ocean-based renewables is a crucial element of reaching global clean energy goals. The International Renewable Energy Agency (IRENA) estimates that offshore wind capacity would grow significantly to 1,000 gigawatts (GW) by 2050-up from 23 GW at the end of 2018-to achieve the necessary transformation of the global energy system (IRENA 2019). Given the scale of investment and public support required, national governments have a major role in facilitating oceanbased renewable energy. Recent analysis from the High-Level Panel for a Sustainable Ocean Economy estimates that by 2050, with appropriate political and policy signals and investment from governments and industry, ocean-based renewable technologies could generate between 760 and 5,400 terawatt-hours (TWh)/year-enough to power approximately 73 to 519 million homes (Hoegh-Guldberg et al. 2019). ${ }^{12}$ 
Offshore wind is an increasingly mature and competitive technology-recent contracts reveal that offshore wind has reached cost parity with fossil sources of electricity (Haugan et al. 2020). The cost of electricity from offshore wind has declined by 18 percent per doubling of capacity (IEA 2020a, 2020b) and presently approaches $\$ 50 /$ megawatt-hours (MWh) in Europe (Ørsted 2019). The recent expansion of offshore wind indicates that its economics have changed markedly within a very short time span and that it could be cost-competitive in many markets now using present-day technologies. This is coupled with increasingly optimistic scenarios for annual electricity demand (TWh/year) (IEA 2020a, 2020b; Haugan et al. 2020), supporting upper estimates of the mitigation potential of this technology. The major hurdles for delivering the full mitigation potential may therefore be largely political, creating significant opportunity for inclusion of targets in NDCs.

Offshore wind projects need good, reliable wind resources and unlike many other forms of renewable energy can be located near areas of high coastal population density, so supply is matched with demand. This allows a more direct route for the delivery of electricity to energy users, which in turn can reduce transmission costs and the challenges of building power lines across land (although there is still the requirement for transmission lines and connection to the main grid). Any efforts to scale offshore wind generation will need to go hand in hand with land-based strategies. The variable nature of offshore wind currents can cause issues for system operators; however, they tend to be much more stable than land-based wind currents and are better able to provide around-the-clock power to match demand. Where there are variability issues, these can be addressed by colocating generation with storage systems such as batteries, which can help to smooth out grid volatility created from overgeneration at times of low demand.

Advances such as floating platforms will increase the economic potential of offshore wind by opening up larger areas to development than is currently possible with fixed-bottom foundations. This could unlock deep-water offshore wind power, which is relevant to regions and countries with limited continental shelf areas. Although most offshore wind development to date has taken place in Organisation for Economic Co-operation and Development (OECD) countries, there is enormous potential for developing countries, including Small Island Developing States (SIDS), to benefit from this momentum and ramp up their local offshore markets (World Bank 2019).
Other marine energy technologies_including tidal (both current and range), ocean thermal, salinity gradient, and wave-are currently less well developed than other renewables, yet have the potential for over 300 GW generation capacity and 500 million tonnes of $\mathrm{CO}_{2}$ reductions by 2050 (OES 2017) (see Box 5 below). Of these technologies, tidal generation is the most advanced. There are currently two utility-scale tidal range plants in operation, one in France and one in South Korea. Meanwhile, the MeyGen tidal energy project in Scotland-scheduled for completion in 2021 - will be the world's largest tidal stream energy plant, with 269 turbines and a capacity of 398 MW, enough to power 175,000 homes (EDF 2016; The Guardian 2016). Ocean thermal, salinity gradient, and wave technologies are at various stages of development and not currently ready for utility-scale deployment. For those countries that are able to do so, putting in place clear national targets or supportive policies and measures in NDCs could be a stimulus and catalyst to these industries.

As with any large-scale infrastructure development, addressing potential environmental impacts and resource conflicts with other ocean uses early and effectively will maximize the overall benefits of offshore renewable energy development. For example, countries should consider, and take steps to minimize, potential impacts related to marine species and fisheries, conflicts with other industries, and unintended consequences such as changes in vessel traffic patterns that could result in increased emissions. Comprehensive integrated ocean management approaches using tools like marine spatial planning, along with soliciting meaningful stakeholder input early in the siting process, should be used to help avoid or mitigate conflicts with other ocean uses and resource values and ensure installations are appropriately sited and environmentally responsible (Winther et al. 2020; Best and Halpin 2019). Recent analysis indicates that potential impacts of marine renewable energy on marine life are likely small or undetectable (Copping and Hemery 2020), with evidence of long-term positive effects on marine species through habitat creation (i.e., energy infrastructure providing habitat) and reduced fishing pressure from trawling in the vicinity of energy generation (IRENA 2018b; Dinh and McKeogh 2019).

Specific options for including ocean-based renewable energy in the mitigation component of NDCs are contained in Table 5. 
The UK government developed a new Industrial Strategy in 2018 that included a Sector Deal for offshore wind. In March 2019, the government pledged to deliver a total installed offshore wind capacity of 30 GW by 2030 (Government of United Kingdom 2019b.) Central to the development of a specific target for offshore wind is a partnership with the private sector to invest in supply chain development and energy infrastructure. In return for this long-term commitment from the government to deliver capacity, the industry pledged to increase local content and invest in local supply chains. With the introduction of the Contract for Difference mechanism in 2015, the United Kingdom has seen the cost of offshore wind fall by over 60 percent and is now delivering electricity below the wholesale market electricity price (Government of the United Kingdom 2019a and b).

This commitment was recently strengthened by the UK government following the announcement confirming that offshore wind will produce more than enough electricity to power every home in the United Kingdom by 2030 - strengthening the previous 30 GW target to $40 \mathrm{GW}$ and creating a new target for floating offshore wind to deliver $1 \mathrm{GW}$ of energy by 2030, which is over 15 times the current volume worldwide (Government of the United Kingdom 2020). The current installed capacity in the United Kingdom is approximately 8.5 GW, or 9 percent of demand. Total installed capacity at $40 \mathrm{GW}$ by 2030 would avoid emissions of 70 million tonnes of carbon dioxide equivalent $\left(\mathrm{CO}_{2} \mathrm{e}\right), 160,00$ tonnes of sulphur dioxide $\left(\mathrm{SO}_{2}\right)$, and 100,000 tonnes of nitrogen oxides $\left(\mathrm{NO}_{\mathrm{x}}\right)$, and save 2.2 trillion liters of water in 2030 (annual figures).

Germany currently has a target of $15 \mathrm{GW}$ of installed capacity by 2030 and may soon increase its 2030 target to $20 \mathrm{GW}$ and adopt a 2040 target of 40 GW (Bundesministerium für Wirtschaft und Energie 2020). The Netherlands has also set a target of 11.5 GW installed capacity by 2030 (Wiebes 2018). Finally, the European Commission's zero-carbon roadmap increases its offshore wind capacity to 600 GW by 2050

With EU countries outlining their commitments for new renewables in their 2030 National Energy Plans, there is an opportunity to advance specific offshore renewable energy targets.

Source: Authors.

Table 5 I Options for Incorporating Targets, Policies, and Measures for Ocean-Based Renewable Energy into New or Updated NDCs

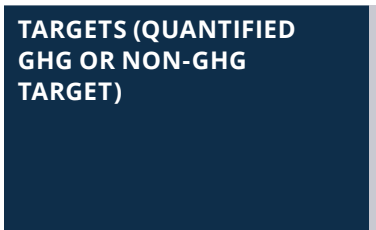

POLICIES AND MEASURES

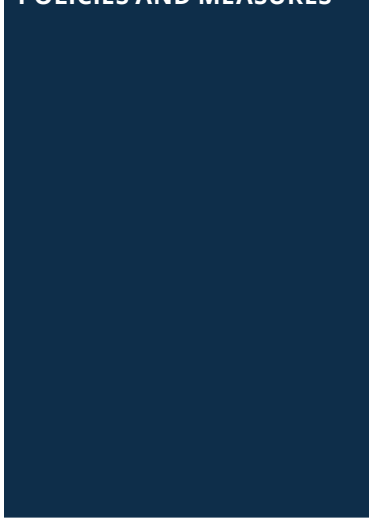

- Expand and increase the ambition of existing economy-wide GHG targets by including emission reductions from scaling ocean-based renewable energy production.

- Define capacity and/or generation targets for ocean-based renewable energy (e.g., offshore wind within EEZ, and tidal and wave energy). Such targets could be expressed as absolute quantities, a percentage increase from current levels, and/or as a share of the total energy or electricity mix.

- Commit to developing inclusive National Marine Spatial Planning Frameworks and/or Integrated Ocean Management to map ocean-based activities and area-based management tools, to identify opportunities for expanding offshore renewable energy that balances the needs of other ocean users and the sustainability of coastal and marine ecosystems.

- Commit to developing a clear, streamlined, and centralized permitting process without compromising the necessary environmental impact assessments and participation of local communities and stakeholders.

- Commit to investing in grid infrastructure and the necessary connections to ensure offshore wind farms or other ocean-based renewables can connect into the grid.

- Commit to R\&D and demonstration projects and pilots for less advanced ocean-based renewable energy technologies that are not yet commercially viable (e.g., tidal, current, or floating solar).

- Commit to R\&D to explore opportunities to align ocean-based renewable energy with efforts to decarbonize marine transport and aquaculture and support coastal and marine ecosystems.

Note: $\mathrm{EEZ}$ = Exclusive Economic Zone.

Source: Authors. 


\section{Ocean-Based Adaptation Options}

More than 40 percent of the global population lives in coastal areas, and approximately 3.3 billion people depend on fish as a primary source of protein (UN Sustainable Development Knowledge Platform 2017; FAO 2020). The Paris Agreement includes the aim to increase "the ability to adapt to the adverse impacts of climate change and foster climate resilience and low greenhouse gas emissions development" (Article 2.1). It also establishes the global goal of "enhancing adaptive capacity, strengthening resilience, and reducing vulnerability to climate change" (Article 7.1). Implementing a holistic portfolio of adaptation strategies can help the ocean, and the local coastal communities and the economies that rely on it, to be resilient to unavoidable impacts.

In their NDCs, countries have the opportunity to communicate how they intend to contribute to these global goals by enhancing adaptive capacity and resilience in their own jurisdictions and by supporting other countries to do the same. While the inclusion of adaptation in NDCs remains optional, a significant majority of countries have opted to incorporate adaptation in the first round of NDCs, and it is likely that upcoming NDC enhancements will continue to reflect adaptation priorities to varying degrees.

In 2018, the Parties to the Paris Agreement identified the following purposes for the Adaptation Communication, some or all of which may mirror a country's own priorities for including adaptation in the NDC (UNFCCC 2018):

- Increase the visibility and profile of adaptation and its balance with mitigation

- Strengthen adaptation action and support for developing countries

- Provide input to the global stocktake

- Enhance learning and understanding of adaptation needs and actions

Because NDCs are high-profile documents, internationally and often domestically, elaborating the adaptation contents in the NDC can increase the visibility and profile of adaptation (Fransen et al. 2017).
This section of the guide provides a set of options for how ocean-based national adaptation priorities, strategies, policies, plans, goals, and actions (based on the elements for an Adaptation Communication in decision 9/CMA.1) can be incorporated into the adaptation component of new or updated NDCs (as a whole or part of a country's Adaptation Communication pursuant to Article 7 of the Paris Agreement). For more detailed guidance on steps and relevant considerations for enhancing the adaptation component of an NDC, please see the overarching guide, Enhancing NDCs: A Guide to Strengthening National Climate Plans (Fransen et al. 2019).

\section{COASTAL AND IMARINE ECOSYSTEMS}

Protecting marine and coastal habitats and their services can confer adaptation benefits to coastal populations as well as to marine species (Duarte et al. 2013). In addition to protecting food security, habitats such as mangrove forests, seagrass meadows, wetlands, and coral reefs can protect against sealevel rise and storm surge and improve coastal water quality. Recent estimates revealed that mangroves are worth at least $\$ 1.6$ billion each year in ecosystem services that support coastal livelihoods and human populations around the world. These ecosystems can also reduce damage from storms and floods by 40 to 60 percent while stabilizing shorelines, reducing erosion, and protecting freshwater reservoirs and agricultural land from saltwater intrusion (Badola and Hussain 2005; Das and Vincent 2009; IPCC 2012).

Countries can use a suite of strategies and area-based conservation measures, including smartly designed, well-enforced, and well-managed marine protected areas (MPAs), to make ocean ecosystems and the communities that rely on them more resilient to the impacts of climate change and to increase ocean biodiversity (Merwin et al. 2020).

A growing number of countries such as the Seychelles, Palau, Fiji, and Chile have adopted a domestic target to protect 30 percent of the ocean within their EEZs by 2030 as a key measure to improve the resilience of their coasts, coastal economies, and coastal ecosystems. The inclusion of such domestic targets 
are ripe for reflection in adaptation components of their NDCs. These national efforts are part of the broader global call by scientists, governments, and nongovernmental organizations (NGOs) to protect 30 percent of the world's oceans by 2030 (Dinerstein et al. 2019; IUCN 2016).

The designation and management of "climate-smart" MPAs that are planned using climate information can enhance resilience to climate change through several mechanisms:

- Improving adaptative capacity: The ability of a species to adapt to climate change depends on population size and adequate genetic diversity. Species and genetic diversity are often greater in marine reserves compared to harvested areas (Bernhardt and Leslie 2013). Hence, there is a higher probability that at least some individuals, or species, will survive and thrive under changing environmental conditions (Baskett and Barnett 2015).

- Providing connectivity for migrating fish stocks: By enhancing connectivity between populations, species, and ecosystems, well-designed MPAs can help reduce recovery times through replenishment of less protected regions following disturbances (Bernhardt and Leslie 2013). When populations remain connected across seascapes via dispersal, depleted populations can be reseeded from nearby healthy populations. If designed with climate impacts in mind, establishing networks of reserves across environmental and spatial gradients can also provide stepping stones for species as their distributions shift poleward and into deeper water due to warming (Roberts et al. 2017).

- Providing climate refugia: In regions where the environment is changing more slowly, establishing protected areas could serve as climate refuges, or the last remaining safe havens, for vulnerable species and ecosystems (Roberts et al. 2017). For example, model projections for rising sea surface temperatures and ocean acidification suggest that the central and western Indian Ocean and regions in the Atlantic might serve as refuge for tropical coral reefs (Couce et al. 2013).
- Mitigating ocean acidification: There is growing interest in the role that some species or habitat types, such as shellfish reefs, mangroves, kelp forests, and seagrass beds, can play in mitigating ocean acidification locally through their biogeochemistry (Kroeker et al. 2019). This is a topic of ongoing experimentation and may be a benefit of protected areas in certain circumstances.

These benefits may also be true for OECMs - geographically defined areas other than a protected area that are governed and managed in ways that achieve positive and sustained longterm conservation outcomes with ecological, cultural, socioeconomic, and other locally relevant benefits.

Effective MPAs and OECMs should be collaboratively designed with clearly identified goals, incorporate and address projected climate impacts, take advantage of natural refugia and connect biologically rich areas, and be well-enforced, well-managed, and monitored. Protected areas should cross a gradient of environmental conditions and include multiple representative habitat types, such as mangroves, coral, and seagrass beds (McLeod et al. 2009). Community and equity considerations must be considered in terms of siting, planning, and management of MPAs. For example, MPAs must be designed considering the rights of Indigenous Peoples and must be managed and governed equitably and effectively (IUCN 2017b).

Specific options for including coastal and marine ecosystems in the adaptation component of NDCs are contained in Table 6. 


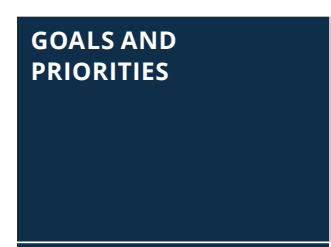

STRATEGIES, POLICIES,

PLANS, AND ACTIONS
- Target at least 30\% of EEZs under high protection through Marine Spatial Plans (MSPs), discrete MPAs, Ramsar sites, or OECMs, incorporating best available science on expected reduced climate impacts.

- Manage effectiveness goals related to science-based development, enforcement, and implementation of MPAs; for example, a percentage of management or administrative plans will be implemented with monitoring and community involvement.

- Incorporate climate-relevant elements into MPA and OECM network design, including specific ecosystem-based adaptation measures and indicators.

- Identify long-term ecosystem indicators that can inform monitoring and adaptative management.

- Update management plans for coastal blue carbon sequestration to fully account for rising seas, intensifying storms, and altered hydrology and salinity.

- Pilot large-scale shallow-water reforestation using kelps in the temperate zone to provide critical habitat, to dampen wave energy, and to partially counteract ocean acidification in the reforested area.

- Reform fiscal policies to invest in and incentivize restoration, sustainable management, and protection of coastal and marine ecosystems to enhance adaptation and resilience of coastal communities.

- Pursue policies to empower and encourage community restoration and stewardship, including community-based adaptation approaches that improve land tenure (including of coastal and marine ecosystems) and legal recognition of indigenous territories.

- Develop innovative financing to promote coastal and marine protection and restoration efforts (e.g., insurance, blue bonds, debt-for-nature swaps, and resilience credits).

- Implement a system of monitoring and evaluation (e.g., reef check surveys, etc.) of productivity of coastal and marine ecosystems.

- Measure and transparently report on wave intensity as a proxy for ecosystem resilience and risk reduction from national disasters.

- Increase and strengthen the capacity of municipal authorities and related ministerial departments to ensure developments within the coastal and urban areas have complementary approaches that integrate ecosystembased measures.

Note: MPAs = Marine protected areas; OECMs = Other effective area-based conservation measures.

Source: Authors.

\section{OCEANIC AND COASTAL FISHERIES}

Both small-scale and industrial fisheries are particularly vulnerable to climate change, which has the potential to affect profitability, food security, and poverty rates while also increasing the potential for conflict among fishers and across political jurisdictions (Pinsky et al. 2018). Warming ocean temperatures and changing ocean chemistry - as well as resulting habitat degradation and food-web alterations-are already affecting fisheries' productivity and causing fish population distributions to shift their ranges toward the poles or into deeper waters. A majority of scientific models predict that polar regions will see a net increase in productivity; temperate zones will see relatively stable productivity but shifting assemblages of stocks; while the tropics will experience a net loss in fisheries production (Hollowed et al. 2013). These changes pose potentially catastrophic impacts for communities that rely on sustainable fishing for livelihoods, especially those of Small Island Developing States (SIDS).

Rising temperatures are also impacting overall fisheries productivity. While climate change could significantly lower global catch under the worst warming scenarios, the rapid implementation of climate adaptive fisheries management could offset many 
potential losses and lead to better outcomes in almost all fisheries (Barange et al. 2018; Gaines et al. 2018). Ecosystem management approaches can confer resilience for fisheries and ameliorate climate impacts, but such approaches will not be sufficient under continued change; there remains a need to more fully integrate climate in management and enable new and transformative solutions, given the magnitude of change anticipated (Holsman et al. 2020).

Committing to climate-smart fisheries policy and management solutions through new or updated NDCs can be a critical tool to advance community- and ecosystem-based adaptation (see Box 6). There are myriad opportunities that countries may incorporate in the adaptation component of their NDCs, Adaptation Communications, and National Adaptation Plans (NAPs), includ- ing various components of the fisheries sector and management actions. Importantly, fisheries and fishing communities are diverse and local, thus national governments should use that flexibility not only to tailor adaptation efforts to specific geographies, cultures, socioeconomics, and environments but also to engage local stakeholders in public consultations when developing these policies.

Similar in many respects to conventional adaptive management in fisheries, climate-specific adaptation in this sector should also be implemented as an iterative process that includes the following steps:

- Establish sound and precautionary fisheries management: Fisheries that have sound management policies and institutions perform significantly better than those that do

\section{Box 6 | Improving the Resilience of Small-Scale Fishers through Ecosystem-Based Adaptation (EbA)}

Improving the resilience of small-scale fishers through promoting and applying the principles of ecosystem-based adaptation (EbA) can be an important driver to support the adaptation of national fisheries as a whole. Recognizing the important role that smallscale fisheries and coastal communities play in adaptation (e.g., improving food security, enhancing local biodiversity, and ensuring economic diversification) and including specific goals, priorities, policies, and actions in the adaptation component of an NDC can greatly contribute to national and global adaptation goals.

Indonesia's efforts to promote EbA within community-based fisheries management and therefore follow a bottom-up approach to enhancing the resilience of its fisheries sector can provide valuable insights for other governments looking to do the same.

In partnership with Rare, Food and Agriculture Organization (FAO), Global Island Partnership (GLISPA), and Micronesia Conservation Trust (MCT), the government of Indonesia is using a holistic approach to mainstream EbA into the practices of small-scale fishing, and working toward greater ownership of the implementation and monitoring needed at the local and national levels (IKI, 2020). To achieve this, Southeast Sulawesi province recently passed subnational policies and regulations that promote EbA within communitybased fisheries management and annual local government workplans. Using the small-scale fisheries productive sector as a vehicle to mainstream EbA and nature-based approaches enables community members and policymakers to clearly identify tangible and actionable practices that are important for climate adaptation and biodiversity protection. Local officials see these benefits firsthand and are empowered to champion EbA to encourage necessary cross-sectoral and interdepartmental coordination, since fisheries and climate are managed by different departments.

Using the adaptation component of new and updated NDCs to communicate such priorities, policies, and measures can help build the overall resilience of national fisheries and bring about the following:

1. Empower vulnerable coastal fishers to sustainably manage marine reserves using science-based fisheries and climate data coupled with behavior change principles.

2. Create an enabling policy environment that promotes EbA measures in fisheries management and COVID-19 Green Recovery plans at the local and subnational levels.

3. Scale locally led solutions toward national relevance, demonstrating EbA as an effective approach to address climate adaptation and encourage these efforts and stakeholder engagement approaches to be included in national-level reporting and policy processes under the Paris Agreement. 
not (Hilborn et al. 2020). Areas with well-managed fisheries appear to have inherent resilience that those with poorly managed fisheries do not (Free et al. 2019).

- Close the knowledge gap: Climate change will increase uncertainty regarding the economic drivers and social norms and behaviors that underpin current fishing practices and make management through existing regimes more difficult (Miller et al. 2010). An early step in adaptation should be investments in the science, monitoring, and data products needed for effective yet precautionary management and associated measurement, reporting, and verification (MRV). This includes identifying climate information that can minimize these uncertainties, including scenario planning for expected impacts and conducting long-term biophysical monitoring of the system to understand real world impacts. In parallel, management and planning can also be systematically improved to incorporate climate science and ecosystem-based adaptation measures. In large-scale and industrial fisheries, this can be accomplished by, for example, including climate drivers in stock assessment models or developing ancillary indicators (e.g., biophysical, social, or economic) that can act as benchmarks or triggers to adjust management in response to changing conditions (Pinsky and Mantua 2014). To help local fishing communities better adapt and manage their fisheries under increased climate change pressure, innovation in digitalization of catch and sales data will support the adaptive capacity of communities and build resilience of this productive sector. Countries can place greater resources in this area through commitments made in their NDCs.

- Invest in management strategy evaluation: With rapidly changing ocean conditions, fish populations are behaving in novel ways, and historic population time series are becoming less suitable for generating the forecasts necessary for catch advice (Pinsky and Mantua 2014). The analytical technique of management strategy evaluation (MSE) ${ }^{13}$ is a promising approach when data are limited and when climate variability introduces significant uncertainty (Punt et al. 2014).

Meanwhile, qualitative scenario planning and ecological risk assessment (Holsman et al. 2017) can help identify potential management pathways. In the small-scale fisheries sector, this can be achieved in integrating vulnerability assessments into the management of local fisheries and the design of possible reserve areas. Countries can direct greater resources to this area through commitments made in their NDCs.
- Reduce stressors to maintain ecological resilience: Reducing nonclimate stressors on ecosystems and understanding interactions among stressors is critical for building resilience to climate change and for sustainable food production. For example, keeping fishing pressure at or below sustainable levels (e.g., biomass that enables a fish stock to deliver the maximum sustainable yield $\left[\mathrm{B}_{\text {MSY }}\right]$ vs. biomass that maximizes net economic returns in the fishery $\left[\mathrm{B}_{\mathrm{MEY}}\right]$ ) through sustainable management can help populations better weather some impacts of climate change (Gaines et al. 2018) Elements of sustainable fishery management that countries can include as policies or measures in their NDCs include defining criteria for stock status in domestic fisheries; setting and enforcing science-based catch limits; maintaining a healthy base of forage fish; and minimizing catch of nontarget species.

- Enhance community resilience: The needs and practices of a community that fishes for subsistence will differ significantly from one that fishes commercially. To promote community resilience and food security, countries will need to assess and address local and unique challenges and help to foster conditions that enable effective collective action by communities in response to climate threats. For example, in some cases, countries may be able to aid fishing communities in the diversification of income streams through climate-smart fishing portfolios or the addition of other sources of income, such as smallholder agriculture, aquaculture, or tourism (Barange et al. 2018). Community participation and the integration of local and indigenous knowledge into management will be crucial for informing locally relevant policies (Martin et al. 2018; Ban et al. 2017).

- Strengthen governance at multiple scales: To be effective, governance systems for fisheries must be prepared to use climate information and address climate-related needs. Countries commit to develop and implement policies and agreements for managing shifting stocks nationally and internationally, including through regional fisheries management organizations, given that all regions will have to deal with changing stock distributions as a result of climate change (Pinsky et al. 2018). This will likely necessitate new or improved mechanisms that foster international cooperation.

Specific options for including oceanic and coastal fisheries in the adaptation component of NDCs are contained in Table 7. 


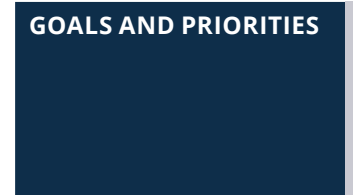

STRATEGIES, POLICIES, PLANS, AND ACTIONS
- Enhance fish stock recovery to support the maximum sustainable yield ( $\left.B_{M S Y}\right)$ as a minimum.

- Reduce nonclimate pressures on fish stocks, including minimizing overfishing, protecting and restoring habitat, pollution management, and reductions in impact and risks from other coastal and ocean uses.

Increase science and data production capacity relevant to fishery management.

- Integrate ecosystem-based adaptation measures into local and national fisheries' plans and budgets, including but not limited to small-scale fisheries.

- Invest in monitoring, data systems, and modeling that can help fisheries predict and adapt to changes and support adaptation.

- Transparently report on data systems and modeling that can improve understanding of changes in fish stocks to support sustainable and adaptive fisheries management.

- Commit to transition to a system of forward-looking, rather than historically driven fisheries management; for example, set stock status criteria and develop set triggers for environmental conditions that lead to management adjustments.

- Integrate local and indigenous knowledge and community-based adaptation actions into local and national fisheries plans and budgets_-including secure tenure and fishing rights_to strengthen community resilience (Reddy 2016; Ban et al. 2017).

- Enhance regional and local cooperation to more effectively manage stocks that shift across political boundaries.

- Invest in skill and capacity building in local communities to support sustainable management.

- Develop policies and governance structures that involve community and stakeholder participation, and base decisionmaking on principles of fairness and equity.

- Commit to community-based adaptation approaches that improve resilience and food security, particularly in smallscale fisheries and coastal communities.

- Commit to support livelihood diversification programs that reduce nonclimate pressure on fish stocks.

Source: Authors.

\section{OCEAN ACIDIFICATION}

Atmospheric $\mathrm{CO}_{2}$ levels are rising, and the ocean absorbs about 22 percent of this $\mathrm{CO}_{2}$ as it dissolves into surface seawater, decreasing $\mathrm{pH}$ and causing ocean acidification (Friedlingstein et al. 2019). This has serious effects on ocean life. Swimming snails, corals, clams, oysters, scallops, mussels, and certain finfish do not survive as well or grow as quickly. Coral reef ecosystem diversity decreases with acidification, and macroalgae and seagrasses can take over seafloor environments. Model projections suggest that the composition and biomass of pelagic ecosystems can greatly change in response to acidification. Overall, acidification can substantially change the makeup and function of underwater ecosystems. Ocean acidification also interacts with other ocean changes such as rising temperature, decreasing oxygen concentrations, and local drivers to affect marine ecosystems further (IPCC 2019).

Ocean acidification also has serious effects on human economies, coastal communities, and regulating and provisioning ecosystem services. It is projected that by 2100 acidification could degrade global coral cover by approximately 31 percent and could lead to $\$ 40$ billion in reductions in seafood production from mollusk reefs (Gaines et al. 2019). Both coral and mollusk reefs protect coastlines from storm waves, which themselves are stronger and higher because of climate change, putting coastal communities at even greater risk. Warming multiplies 
the threat: warm-water corals are at very high risk due to warming, ocean acidification, and other climate hazards even if global warming can be limited to $1.5^{\circ} \mathrm{C}$ (IPCC 2019). Economically important industries, including the following, are under threat from acidification as well:

- Aquaculture: Acidification hinders shellfish aquaculture, a growing sector worldwide and part of the marine aquaculture sector, which yielded 30.8 million tonnes of marine food fish and animals globally in 2018 (FAO 2020). In the United States, for example, the $\$ 270$ million/year Pacific oyster industry experienced acidification conditions that contributed to the loss of up to 80 percent of shellfish larvae for several seasons in a row in the 2000s.

- Fisheries: Acidification and warming can cause decreasing or shifting fish stocks, threatening many of the estimated 3.3 billion people who rely on fish for nearly 20 percent of their animal protein intake (FAO 2020). It also drives the collapse of coral and shellfish reefs, which are essential for supporting wild fish stocks.
- Tourism: Acidification and warming damage coral habitats, which generate $\$ 36$ billion in global tourism per year (Spalding et al. 2017).

Nutrient enrichment can amplify the rate at which ocean acidification can take place. For Caribbean economies that are heavily dependent on coral reef-based fisheries, net revenues of \$95-\$140 million/year could be lost if measures to reduce nutrient levels, such as proper waste treatment, are not enacted (Gaines et al. 2019). Policies are therefore needed to incorporate proper waste treatment facilities as part of coastal tourism development, to minimize nutrient enrichment to coastal oceans.

Specific options for including measures to improve resilience to ocean acidification in the adaptation component of NDCs are contained in Table 8.

Table 8 | Options for Inclusion of Ocean Acidification in the Adaptation Component of New or Updated NDCs

STRATEGIES, POLICIES, PLANS, AND ACTIONS

- Commit to designing and implementing a long-term ocean acidification observing network with quality standards sufficient to detect a change in key at-risk assets such as local fisheries or iconic ecosystems.

- Devise strategy for promoting partnerships among researchers and coastal resource users to identify innovative paths forward (e.g., selective breeding of resistant species such as acidity-adapted shellfish for mariculture).

- Commit to reducing local land-based contributions to acidification, including runoff of nutrients, sediment, organic carbon, storm and wastewater, and pH-active substances.

- Introduce land and aquatic vegetation-based systems to remediate the impacts of acidification.

- Devise strategy to establish knowledge exchange among experts and key sectors, such as the aquaculture industry.

- Introduce grants, loans, tax incentives, and permitting to help future-proof businesses reliant on coral reef tourism.

- Commit to assess the influence of existing coastal management policies and practices on acidification to avoid unintentional maladaptation to the total effects of ocean change.

- Invest in monitoring, laboratory studies, and science synthesis to assess the risks to local communities and economically and culturally important marine species and resources.

- Commit to quantifying finance (and tech technology and capacity-building) necessary to implement acidification-focused policies and measures.

Source: Authors. 


\section{Financing Ocean-Based Climate Action}

For developing coastal countries on the frontlines of ocean and climate change, increasing the ambition of ocean-related mitigation and adaptation action in NDCs will require-and will signal a demand for-increased international finance for implementation.

Funding is available from several sources of multilateral support, such as the Adaptation Fund, the Green Climate Fund, the Global Environmental Facility, the Least Developed Countries Fund, and the Special Climate Change Fund. Each of these channels of international climate finance has supported ocean-climate projects in recent years. The Adaptation Fund, for example, has recently supported projects intended to help communities adapt to coastal erosion in vulnerable areas of Senegal and to reduce vulnerability to coastal flooding through ecosystem-based adaptation in Cuba (Adaptation Fund 2015), while the Green Climate Fund is currently supporting a project in India that aims to increase the resilience of coastal communities by protecting and restoring coastal ecosystems including mangroves and seagrasses (The Green Climate Fund 2018). However, it is worth noting criticism of these funds based on the difficulties in accessing funds and for delays in receiving disbursements.

Funding may also be available from multilateral development banks. In particular, the Asian Development Bank (ADB)'s Action Plan for Healthy Oceans and Sustainable Blue Economies, announced in 2019, "will expand financing and technical assistance for ocean health and marine economy projects to \$5 billion from 2019 to 2024, including cofinancing from partners" (ADB 2019). One of the plan's focal areas is "protecting and restoring coastal and marine ecosystems and key rivers" (ADB 2019), which offers a specific opportunity for oceanclimate funding.

In addition, a variety of innovative finance options have emerged in the past five years. For example, the Seychelles recently took advantage of an opportunity that helps coastal nations restructure their sovereign debt to redirect a portion of the debt payments to marine conservation and lengthen repayment periods in exchange for committing to protect at least 30 percent of their Exclusive Economic Zone. Since taking advantage of this program, the Seychelles has gained access to an additional $\$ 430,000$ per year for marine conservation and, in 2018, announced marine protected areas of more than 80,000 square miles (TNC 2019b). The Nature Conservancy estimates that upward of 85 countries could use such methods for marine protection (TNC 2019a). Also, in 2018, the Seychelles announced the first sovereign "blue bond" to support fisheries management and marine protected areas by harnessing capital markets for financing the sustainable use of marine resources (World Bank 2018).

Countries may also wish to explore the potential of innovative insurance products to improve the resilience of ocean ecosystems and resources to climate risks. Recently, for example, the Mexican state of Quintana Roo partnered with The Nature Conservancy and insurance company Swiss RE to insure the Mesoamerican Reef against hurricane damage, described in further detail in Box 7 below (SwissReGroup n.d). Similarly, the Pacific Community and the United Nations Pacific Financial Inclusion Programme are currently looking into the possibility of a fisheries insurance program for Pacific Island states (UNDP in the Pacific 2018). Though not appropriate in all circumstances (Kousky and Light 2019), and while care should be taken to adequately account for equity and justice considerations in the design of these programs, including traditional land rights, insurance programs like these can be excellent sources of funding for ecosystem conservation and restoration work.

The Ocean Risk and Resilience Action Alliance (ORRAA), developed by Canada, AXA XL, and Ocean Unite is another instance of growing interest and opportunity in this sector. This new initiative is bringing together organizations from the public and private sectors and civil society to develop risk management strategies using the experience and expertise of the insurance and broader finance community, alongside the knowledge of the ocean community. 
A key role for these funds and initiatives is to develop and demonstrate a pipeline of bankable projects so private investors, as well as multilateral development banks, will find the right ways to identify and invest in high-impact projects (Thiele et al. 2020). Efforts such as IUCN's Blue Natural Capital Financing Facility are supporting project developers with a clear return-on-investment business idea, built on or supported by coastal nature-based solutions, including blue carbon.

Lastly, countries could also explore the potential of carbon markets, including the voluntary carbon market, as a way to finance efforts to protect and manage blue carbon ecosystems. In addition to opportunities for financing carbon through these markets, efforts are underway to develop a resilience credit for coastal and marine ecosystems to improve the resilience of coastal infrastructure under The Nature Conservancy's Sustainable Development Verified Impact Standard (SDVISta)—a program that provides investors with metrics that help quantify how their support will strengthen resiliency in vulnerable coastal communities under SDG 13 (TNC 2019a).

As ocean issues become better integrated into the international climate effort, a comprehensive mapping of the supply of-and demand for-international ocean-climate finance (including quantifying the size of the finance gap) would be a helpful step toward unlocking the mitigation and resilience potential of the ocean to protect developing coastal communities and their ocean and coastal ecosystems.

\section{Box 7 | Case Study on Innovative Insurance Mechanisms to Improve Resilience of Coastal Tourism and Infrastructure in Quintana Roo}

The policy that protects the Mesoamerican Reef in Quintana Roo is a form of "parametric insurance," meaning that it disburses funds automatically when conditions exceed a predetermined threshold-in this case when the insured region experiences winds above 100 knots (IYOR 2018b). Once disbursed, the funds will be used for reef restoration work conducted by trained volunteers known as Guardians of the Reef. According to The Nature Conservancy, "40 Guardians of the Reef volunteers were trained in Puerto Morelos in 2018," and 20 more were scheduled to "participate in an additional training [in June 2019] in Isla Mujeres, bringing the total number of trained reef guardians to 60 in this region" (TNC 2019b).

The policy pays into the Coastal Zone Management Trust, a fund established by The Nature Conservancy, the government of Quintana Roo, and the Hotel Association of Cancun and Puerto Morelos, and funded by the government and taxes on tourism (Light and Kousky n.d.; IYOR 2018b). This same fund also pays the insurance premiums (IYOR 2018a).

Healthy reefs attenuate wave energy by over 90 percent (Ferarrio et al. 2014), significantly reducing both storm surge and erosion. The reef is also one of the main tourist attractions in the area. By helping to ensure that the reef remains healthy, this insurance policy thus helps to increase the resilience not only of the area's infrastructure and beaches but also of the $\$ 10$ billion tourism industry centered on tourist hotspots Cancun and Tulum (Tercek 2018).

Source: Authors. 


\section{Conclusion}

To address the interrelated ocean and climate crises, countries and stakeholders must significantly increase the ambition of their national climate actions to be consistent with the goals of the Paris Agreement-maximizing the potential of sustainable ocean-based mitigation measures and adaptation efforts to protect ocean ecosystems and ocean-dependent communities and economies.

These measures are particularly necessary in light of the COVID-19 pandemic, which has impacted blue economy sectors such as fishing, seafood production, tourism, and marine transport. Given that most of the 3 billion people that rely on the ocean for their livelihoods live in developing countries, investment that targets reducing emissions and building future resilience while also providing for a sustainable blue recovery can achieve multiple goals and help to reduce future vulnerabilities to shocks, whether they are climate-related or not, particularly for the most vulnerable.

NDCs can be a critical vehicle for advancing greater action on ocean-based solutions, and vice versa, looking to the ocean economy can be a source of ambition and innovation to enhance economy-wide climate action. NDC-related oceanbased mitigation and adaptation targets, policies, and measures can send the necessary long-term policy signals and trigger the required levels of finance, research and development, and action. The options presented in this guide can be implemented immediately, based on knowledge, accounting methodologies, and technologies that are already available.
The ocean is critical to human well-being, as well as to the stability of the earth's climate and ecosystems. Ensuring the continued robustness of the range of climate and ecosystems, biodiversity, and the intrinsic benefits that the ocean provides requires governments to undertake ambitious and expeditious measures to reduce greenhouse gas emissions from both the land and ocean sectors and to take advantage of natural sinks, as well as to ensure the resilience of marine and coastal ecosystems to benefit the people that depend on them.

This paper has shown the strong potential for enhanced climate ambition through the inclusion of ocean-based targets, policies, and measures in new or updated NDCs. Ultimately, bold political leadership and clear policy signals will be required to capitalize on the full potential of the ocean-based actions identified; this must be coupled with strong national institutions and international cooperation to ensure their effective implementation. 


\section{Additional Resources on Including Ocean-Based Climate Action in Enhanced or New NDCs}

Governments and policymakers wishing to understand, incorporate, or enhance ocean-based climate action in their NDCs can be guided by the following additional knowledge products:

\section{Blue Carbon and Nationally Determined Contributions:} Guidelines on Enhanced Action (The Blue Carbon Initiative 2020).

- This report supports countries seeking to promote and preserve blue carbon/coastal wetlands by providing technical guidance on the multiple avenues through which they can be included within new and updated Nationally Determined Contributions (NDCs) to the Paris Agreement, and can thus contribute to countries' raised ambitions. The report presents a "tiered approach," similar to that employed by IPCC guidance, to demonstrate how a variety of motivations and starting points all represent viable pathways for the inclusion of coastal wetlands in NDCs.

Ocean and Climate Discussion Series: "Climate-Smart" Marine Protected Areas for Mitigation and Adaptation Policy (Merwin et al. 2020).

- This brief reviews the potential climate benefits of marine protected areas (MPAs), discusses how policymakers and practitioners can help ensure that MPAs are "climate-smart," and underscores that, because a suite of mitigation and adaptation policies is necessary to address the climate challenge, climatesmart MPAs merit a place in the climate policy toolbox.

The Ocean as a Solution to Climate Change: Five Opportunities for Action (Hoegh-Guldberg et al. 2019).

- This high-level report seeks to provide a robust science base and practical recommendations for action across issues central to the attainment of a sustainable ocean economy.

\section{Opportunities for Increasing Ocean Action in Climate \\ Strategies (Gattuso et al. 2019).}

- This policy brief provides analysis on a menu of ocean-based measures that can be considered when framing new mitigation and adaptation components of NDCs. Results are packaged in the following four policy clusters:

- Decisive - Effective measures to address climate change and reduce climate-related ocean drivers
- Low regret - Measures that provide dual benefits (climate and other co-benefits)

- Unproven - Measures that can only be achieved with technological evolution (e.g., carbon capture and storage [CCS], marine bioenergy)

- Risky - Measures that require greater public acceptance and international governance (e.g., ocean fertilization and cloud brightening) before any implementation can occur

\section{Guide to Including Nature in Nationally Determined} Contributions (Beasley et al. 2019).

- This guide includes a checklist of information and accounting approaches for natural climate solutions. Information technology (IT) is intended to be a resource for countries as they consider how to use natural climate solutions-such as forests, agricultural lands, and coastal wetlands - to achieve their climate goals. The checklist details information relevant for NDC enhancement using conservation, restoration, and management activities for all ecosystems; the coastal wetlands section explores considerations specific to those ecosystems. Available in English, Spanish, French, and Portuguese.

Ocean for Climate (Because the Ocean 2019).

- Compiled by the Secretariat for Because the Ocean, this paper highlights the importance of coupling climate and ocean ecosystems into decision-making but focuses primarily on ocean elements (increased mitigation actions, implications for ocean activities, and opportunities to improve resilience) since they are traditionally omitted from global discussions. The paper looks at actions in five areas that policymakers can explore to incorporate the ocean into climate strategies:

- Opportunities for encouraging natural carbon sequestration by coastal ecosystems

- Importance of continued development of sustainable oceanbased renewable energy options

- Benefits when adaptation and resilience solutions for at-risk communities and ecosystems are promoted

- Added value of implementing hybrid solutions that support adaptation and mitigation actions in the fisheries and aquaculture sector

- Ways to achieve emission reductions in the shipping sector 
Impacts of Climate Change on Fisheries and Aquaculture: Synthesis of Current Knowledge, Adaptation, and Mitigation Options (Barange et al. 2018).

- This FAO Fisheries and Aquaculture Technical Paper offers a comprehensive synthesis of the issue of climate change in marine and inland fisheries and aquaculture at global and regional scales. The paper is framed in the context of poverty alleviation and varied dependencies on fish and fishery resources and is based on model projections, data analyses, and expert assessments. It is aimed primarily at policymakers, fisheries' managers, and practitioners, to assist countries in the development of their NDCs.

\section{Measuring Progress on Ocean and Climate Initiatives: An} Action-Oriented Report (Picourt 2017).

- This report analyzes the role of international initiatives and multistakeholder partnerships in creating more robust scientific knowledge on the linkages between ocean and climate; and in incorporating ocean-based mitigation and adaptation actions as part of the Global Climate Action Agenda.

\section{Pathways for Climate-Ready Fisheries (Burden and}

Battista, 2019)

- This report identifies five key pathways that can be taken by governments, NGOs, fisher organizations, academia and multilateral organizations in order to create greater resilience and sustainability. It also details the necessary social, political, and economic transitions required in order to avoid, or even reverse, the worst impacts from climate change on the world's fisheries and fishing communities.
The 2013 Supplement to the 2006 IPCC Guidelines for National Greenhouse Gas Inventories: Wetlands (Wetlands Supplement) (IPCC et al. 2014).

- This report provides additional information that reflects scientific advances, including an update of previously reported emissions factors. This add-on now comprises additional information on inland organic soils and on wetlands on mineral soils; coastal wetlands including mangrove forests, tidal marshes, and seagrass meadows; and constructed wetlands for wastewater treatment.

Case Studies on Ocean and Climate Change (The Commonwealth Blue Charter Action Group on Ocean and Climate Change 2020).

- Compiled by the Ocean and Climate Change Action Group of the Commonwealth Blue Charter, championed by Fiji, these case studies focus on implementing climate vulnerability assessments (CVAs), implementing community-led blue carbon projects, and reducing GHG emissions at small and medium-sized ports. 


\section{APPENDIX B}

\section{Data to Support Inclusion of Coastal and Marine Ecosystems in National Inventories and Policy}

\section{Table B1 | Mangrove Data for International Policy}

\section{POLICY FRAMEWORK}

United Nations Sustainable Development Goals (SDGs) including SDG 1 No Poverty, SDG 2 Zero Hunger, SDG 6 Clean Water and Sanitation, SDG 13 Climate Action, SDG 14 Life under Water, SDG 15 Life on Land

United Nations Framework Convention on Climate Change

Convention on Biological Diversity

Sendai Framework on Disaster Risk Reduction

Ramsar Convention

Bonn Challenge

IUCN General Assembly and World

Conservation Congress

\section{INFORMATION NEEDS}

Resilience value, mitigation value, food security

(including fish production), and human well-being. Trends in mangrove health and distribution

\section{DATASETS}

Mangrove Tourism, Coastal Protection, Fisheries Enhancement,

Total Carbon, Mangrove Extent, Mangrove Degradation, Effectiveness of Protected Areas for Mangrove Conservation

Mitigation value (carbon stores, sequestration rate, avoided loss, rehabilitation potential). Adaptation value (reduction in flooding, coastal erosion, and wave attenuation). Greenhouse gas inventories: trends in mangrove health and distribution for Tier 1 reporting Trends in health and distribution, including in protected areas; selection of new protected areas based on ecosystem services. Identification of biodiversity hotspots

Coastal protection and food security Status of protected areas (i.e., degraded or not), Ramsar sites in areas of high ecosystem services and biodiversity

Areas for rehabilitation and rehabilitation success

Areas for rehabilitation and rehabilitation best practices. Identification of areas in need of protection and sustainable management
Total Carbon, Coastal Protection, Drivers of Mangrove Extent Change, Mangrove Extent, Mangrove Degradation

Mangrove Extent, Mangrove Degradation, Effectiveness of Protected Areas for Mangrove Conservation, Conservation Hotspots

Coastal Protection, Fisheries Enhancement Mangrove Extent, Mangrove Degradation, Effectiveness of Protected Areas for Mangrove Conservation

Restoration Potential

Restoration Potential, Effectiveness of Protected Areas for Mangrove Conservation, Conservation Hotspots

Source: Worthington, T.A., D.A. Andradi-Brown, R. Bhargava, C. Buelow, P. Bunting, C. Duncan, L. Fatoyinbo, et al. 2020. "Harnessing Big Data to Support the Conservation and Rehabilitation of Mangrove Forests Globally." One Earth 2 (5): 429-43. doi:10.1016/j.oneear.2020.04.018. 
Table B2 | Existing Global Mangrove Datasets

\begin{tabular}{|c|c|c|c|c|c|}
\hline DATASET & DESCRIPTION & NOMINAL YEAR & RESOLUTION & $\begin{array}{l}\text { MANGROVE } \\
\text { EXTENT USED }\end{array}$ & REFERENCE \\
\hline \multirow[t]{5}{*}{$\begin{array}{l}\text { Mangrove extent } \\
\text { and change }\end{array}$} & $\begin{array}{l}\text { Composite extent map using remote-sensing } \\
\text { and visual-interpretation approaches }\end{array}$ & 1999-2003 & - & - & Spalding et al. 2019 \\
\hline & $\begin{array}{l}\text { First globally consistent remote-sensing- } \\
\text { based map of mangrove extent }\end{array}$ & 2000 & $30 \mathrm{~m}$ & - & Giri et al. 2011 \\
\hline & $\begin{array}{l}\text { Dataset refined by the removal of areas } \\
\text { above an elevation threshold }\end{array}$ & 2000 & - & Giri et al. 2011 & Tang et al. 2018 \\
\hline & $\begin{array}{l}\text { Global analyses of mangrove deforestation } \\
\text { based on the GFC dataset }\end{array}$ & $\begin{array}{l}\text { Annual } \\
2000-2012\end{array}$ & $30 \mathrm{~m}$ & - & $\begin{array}{l}\text { Hamilton and Casey } \\
2016\end{array}$ \\
\hline & $\begin{array}{l}\text { Most current global analysis of extent } \\
\text { captures both losses and gains over } \\
20 \text { years }\end{array}$ & $\begin{array}{l}1996,2007- \\
2010,2015 \\
2016\end{array}$ & $25 \mathrm{~m}$ & - & Bunting et al. 2018 \\
\hline Mangrove biomass & $\begin{array}{l}\text { Climate-driven model of potential } \\
\text { mangrove AGB }\end{array}$ & - & - & $\begin{array}{l}\text { Spalding et al. } \\
2019\end{array}$ & Hutchison et al. 2014 \\
\hline \multirow[t]{2}{*}{$\begin{array}{l}\text { Mangrove height } \\
\text { and biomass }\end{array}$} & $\begin{array}{l}\text { Canopy height maps based on a digital } \\
\text { elevation model and lidar altimetry }\end{array}$ & 2000 & $30 m$ & Giri et al. 2011 & Simard et al. 2019 \\
\hline & $\begin{array}{l}\text { Canopy height maps based on a digital } \\
\text { elevation model; biomass derived from a } \\
\text { global allometric model }\end{array}$ & 2000 & - & Giri et al. 2011 & Tang et al. 2018 \\
\hline $\begin{array}{l}\text { Freshwater and } \\
\text { sediment impacts } \\
\text { on mangrove } \\
\text { condition }\end{array}$ & $\begin{array}{l}\text { Changes in mangrove extent are modeled } \\
\text { against human alteration to free-flowing } \\
\text { rivers }\end{array}$ & - & - & $\begin{array}{l}\text { Bunting et al. } \\
2018\end{array}$ & Maynard et al. 2019 \\
\hline $\begin{array}{l}\text { Mangrove } \\
\text { fragmentation }\end{array}$ & $\begin{array}{l}\text { Global analyses of the change in } \\
\text { fragmentation metrics over time }\end{array}$ & $\begin{array}{l}\text { Annual } \\
2000-2012\end{array}$ & $0.2^{\circ} \times 0.2^{\circ}$ & $\begin{array}{l}\text { Hamilton and } \\
\text { Casey } 2016\end{array}$ & Bryan-Brown et al. 2020 \\
\hline \multirow[t]{5}{*}{ Soil carbon } & $\begin{array}{l}\text { Covariates of climate and location data } \\
\text { modeled against measurements of soil } \\
\text { carbon }\end{array}$ & - & $\sim 10 \mathrm{~km}$ & Giri et al. 2011 & $\begin{array}{l}\text { Jardine and Siikamäki } \\
2014\end{array}$ \\
\hline & $\begin{array}{l}\text { Assessment of how soil carbon stocks vary } \\
\text { across latitude, hemispheres, and mangrove } \\
\text { community composition }\end{array}$ & 2014 & - & $\begin{array}{l}\text { Hamilton and } \\
\text { Casey } 2016\end{array}$ & Atwood et al. 2017 \\
\hline & $\begin{array}{l}\text { Fine-scale three-dimensional variation in } \\
\text { soil-carbon density as assessed by machine- } \\
\text { learning approaches }\end{array}$ & 2000 & $30 m$ & Giri et al. 2011 & Sanderman et al. 2018 \\
\hline & $\begin{array}{l}\text { Variation in soil carbon examined in relation } \\
\text { to coastal environmental settings via } \\
\text { climate-geophysical models }\end{array}$ & - & $\sim 25 \mathrm{~km}$ & $\begin{array}{l}\text { Hamilton and } \\
\text { Casey } 2016\end{array}$ & $\begin{array}{l}\text { Rovai et al. } 2018 \\
\text { Available from the } \\
\text { corresponding author } \\
\text { upon reasonable } \\
\text { request }\end{array}$ \\
\hline & $\begin{array}{l}\text { Mangrove soil-carbon stocks across } \\
\text { different classifications of coastal } \\
\text { environmental settings }\end{array}$ & - & $30 m$ & $\begin{array}{l}\text { Hamilton and } \\
\text { Casey } 2016\end{array}$ & Twilley et al. 2018 \\
\hline \multirow{2}{*}{$\begin{array}{l}\text { Aboveground } \\
\text { and belowground } \\
\text { carbon }\end{array}$} & $\begin{array}{l}\text { Field measurements modeled against } \\
\text { latitude for estimating total biomass carbon }\end{array}$ & - & - & $\begin{array}{l}\text { WRI and IIED } \\
1986\end{array}$ & Twilley et al. 1992 \\
\hline & $\begin{array}{l}\text { Mangrove AGB modeled against latitude; } \\
B G B \text { assessed as a relative fraction of } A G B\end{array}$ & - & $\sim 9 \mathrm{~km}$ & Giri et al. 2011 & Siikamäki et al. 2012 \\
\hline
\end{tabular}


Table B2 | Existing Global Mangrove Datasets (Cont.)

\begin{tabular}{|c|c|c|c|c|c|}
\hline DATASET & DESCRIPTION & NOMINAL YEAR & RESOLUTION & $\begin{array}{l}\text { MANGROVE } \\
\text { EXTENT USED }\end{array}$ & REFERENCE \\
\hline Total carbon & $\begin{array}{l}\text { Annual assessment of total carbon stocks } \\
\text { and losses from deforestation }\end{array}$ & $\begin{array}{l}\text { Annual } \\
2000-2012\end{array}$ & $30 \mathrm{~m}$ & $\begin{array}{l}\text { Hamilton and } \\
\text { Casey } 2016\end{array}$ & $\begin{array}{l}\text { Hamilton and Friess } \\
201\end{array}$ \\
\hline Mangrove tourism & $\begin{array}{l}\text { Analysis of TripAdvisor website to identify } \\
\text { mangrove attractions and their usage }\end{array}$ & Up to 2015 & - & - & $\begin{array}{l}\text { Spalding and Parrett } \\
2019\end{array}$ \\
\hline Coastal protection & $\begin{array}{l}\text { Global valuation model of the role of } \\
\text { mangroves in reducing annual coastal flood } \\
\text { damages to people and property }\end{array}$ & 2010 & $20 \mathrm{~km}$ & Giri et al. 2011 & Losada et al. 2018 \\
\hline $\begin{array}{l}\text { Conservation } \\
\text { hotspots }\end{array}$ & $\begin{array}{l}\text { Conservation hotspots identified by the } \\
\text { intersection of threatened megafauna } \\
\text { distributions with areas of high mangrove } \\
\text { loss }\end{array}$ & 2016 & $\sim 20 \mathrm{~km}$ & $\begin{array}{l}\text { Hamilton and } \\
\text { Casey } 2016\end{array}$ & Sievers et al. 2019 \\
\hline
\end{tabular}

Notes: $\mathrm{AGB}=$ Aboveground biomass; $\mathrm{BGB}=$ Belowground biomass; $\mathrm{GFC}=$ Global forest cover; $\mathrm{m}$ = Meters; $\mathrm{km}$ = Kilometers; - = Not available.

Source: Worthington, T.A., D.A. Andradi-Brown, R. Bhargava, C. Buelow, P. Bunting, C. Duncan, L. Fatoyinbo, et al. 2020. "Harnessing Big Data to Support the Conservation and Rehabilitation of Mangrove Forests Globally." One Earth 2 (5): 429-43. doi:10.1016/j.oneear.2020.04.018.

Table B3 | Upcoming Global Mangrove Datasets

\begin{tabular}{|c|c|c|c|c|c|}
\hline DATASET & DESCRIPTION & $\begin{array}{l}\text { NOMINAL } \\
\text { YEAR }\end{array}$ & RESOLUTION & $\begin{array}{l}\text { MANGROVE } \\
\text { EXTENT USED }\end{array}$ & REFERENCE \\
\hline Mangrove degradation & $\begin{array}{l}\text { Changes in the structural condition of mangroves as } \\
\text { identified by vegetation index time series }\end{array}$ & $\begin{array}{l}\text { Triannual } \\
1984-2018\end{array}$ & $30 \mathrm{~m}$ & $\begin{array}{l}\text { Bunting et al. } \\
2018\end{array}$ & $\begin{array}{l}\text { Worthington and } \\
\text { Spalding } 2018\end{array}$ \\
\hline \multirow[t]{2}{*}{$\begin{array}{l}\text { Drivers of mangrove } \\
\text { extent change }\end{array}$} & $\begin{array}{l}\text { Machine learning and decision trees used for } \\
\text { classifying mangrove loss as commodities, human } \\
\text { settlement, erosion, extreme climatic events, or } \\
\text { nonproductive conversion }\end{array}$ & $\begin{array}{l}2000-2005 \\
2005-2010 \\
2010-2016\end{array}$ & $30 \mathrm{~m}$ & Giri et al. 2011 & $\begin{array}{l}\text { Goldberg et al. } \\
2019\end{array}$ \\
\hline & $\begin{array}{l}\text { Shoreline erosion and surface water change used for } \\
\text { identifying erosion hotspots in mangrove forests }\end{array}$ & - & - & $\begin{array}{l}\text { Bunting et al. } \\
2018\end{array}$ & $\begin{array}{l}\text { Bhargava et al. } \\
2019\end{array}$ \\
\hline $\begin{array}{l}\text { Mangrove geomorphic } \\
\text { typology }\end{array}$ & $\begin{array}{l}\text { Mangroves classified according to their geomorphic, } \\
\text { deltaic, estuarine, lagoonal and open coast, and } \\
\text { sedimentary settings }\end{array}$ & 2016 & $25 \mathrm{~m}$ & $\begin{array}{l}\text { Bunting et al. } \\
2018\end{array}$ & $\begin{array}{l}\text { Worthington and } \\
\text { Spalding } 2018\end{array}$ \\
\hline $\begin{array}{l}\text { Protected-area } \\
\text { effectiveness for } \\
\text { mangrove conservation }\end{array}$ & Work ongoing & - & - & $\begin{array}{l}\text { Bunting et al. } \\
2018\end{array}$ & - \\
\hline Restoration potential & $\begin{array}{l}\text { Expert-driven model of environmental conditions } \\
\text { enabling mangrove restoration at the landscape } \\
\text { scale }\end{array}$ & 2016 & - & $\begin{array}{l}\text { Bunting et al. } \\
2018\end{array}$ & $\begin{array}{l}\text { Worthington and } \\
\text { Spalding } 2018\end{array}$ \\
\hline Fishery enhancement & $\begin{array}{l}\text { Field measurements used for modeling mangrove } \\
\text { dependency for invertebrate and finfish species }\end{array}$ & 2016 & $1 \mathrm{~km}$ & $\begin{array}{l}\text { Bunting et al. } \\
2018\end{array}$ & - \\
\hline
\end{tabular}

Notes: $\mathrm{m}=$ Meters; $\mathrm{km}=$ Kilometers $;-=$ Not available.

Source: Worthington, T.A., D.A. Andradi-Brown, R. Bhargava, C. Buelow, P. Bunting, C. Duncan, L. Fatoyinbo, et al. 2020. "Harnessing Big Data to Support the Conservation and Rehabilitation of Mangrove Forests Globally." One Earth 2 (5): 429-43. doi:10.1016/j.oneear.2020.04.018. 


\section{ENDNOTES}

1. Essential for attaining more sustainable and inclusive economic development paths consistent with the UN Agenda for Sustainable Development, including SDG 14 (UNCTAD 2020).

2. Fisheries (including inland fisheries) account for approximately 0.5 percent of global GHG emissions (Barange et al. 2018).

3. For a discussion on climate-smart MPAs, see https://oceanconservancy. org/wp-content/uploads/2020/07/Climate-Smart-MPAs-Brief_ FINAL_07.08.2020.pdf.

4. The Wetlands Supplement provides a framework guide for accounting ocean ecosystems into GHG inventories.

5. Approximately $80 \mathrm{NDC}$ include an existing or future action related to oceans, coastal, or marine ecosystems in either the mitigation or adaptation component of their NDC, based on analysis in ClimateWatch (WRI 2020). Note that according to research conducted by IUCN and TNC, 87 NDCs contained such references.

6. Under The United Nations Convention on the Law of the Sea (UNCLOS) the Exclusive Economic Zone (EEZ) can be generally defined as the 200 nautical mile area that extends from the shore of a coastal state whereby that coastal state has the legal right, freedom, and jurisdiction to both explore and exploit, and the responsibility to conserve and manage, both living flora and fauna and nonliving resources.

7. Fisheries' share of 4 percent of the emissions produced by global food production excludes emissions associated with burning savannah and crop land. Modeling was based on the aggregation and weighting of extant fuel-use data, specific to target species, gear, and/or fishing country, with corrections to account for upstream emissions from fuel production and transport, as well as nonfuel emissions from vessel construction, gear manufacture, refrigerant use, and other factors.

8. Seafood Watch and Dalhousie University developed a useful seafood carbon emissions tool: http://seafoodco2.dal.ca/.

9. Following the International Maritime Organization (IMO) definition of international transport: Shipping between ports of different countries. International shipping excludes military and fishing vessels, includes bulk carriers, oil tankers, and container ships.

10. Following the IMO definition of domestic transport: Shipping between ports of the same country, includes ferries.

11. In addition to supporting achievement of the Paris Agreement, scaling up the share of offshore energy would also support the achievement of SDG 7.2, 7.A, and 7.B.

12. Demand equivalent figures were derived by dividing generation potential figures by the US Energy Information Administration's figure of 10,399 kWh/year (or.1 TWh/year) per home. See https://www.eia.gov/tools/ faqs/faq.php?id=97\&t=3.

13. According to Punt et al. (2014), "Management strategy evaluation (MSE) involves using simulation to compare the relative effectiveness for achieving management objectives of different combinations of data collection schemes, methods of analysis and subsequent processes leading to management actions. MSE can be used to identify a 'best' management strategy among a set of candidate strategies, or to determine how well an existing strategy performs. With the aid of computer simulation, MSE compares and evaluates prospective management options over a wide range of possible realities for the fishery and fish population and identifies management approaches robust to a range of conditions. This technique directly involves stakeholders in the process that evaluates trade-offs between various management approaches."

\section{REFERENCES}

Adaptation Fund. 2015. "Adaptation Fund in Senegal." Adaptation Fund (blog). July 8. https://www.adaptation-fund.org/adaptation-fund-in-senegal/.

Adaptation Fund. 2018. "Adaptation Fund Project Story—Cuba." Adaptation Fund (blog). May 24. https://www.adaptation-fund.org/adaptation-fundproject-story-cuba/.

ADB (Asian Development Bank). 2019. “ADB Launches \$5 Billion Healthy Oceans Action Plan." Manila, the Philippines: Asian Development Bank, May 2. https://www.adb.org/news/adb-launches-5-billion-healthy-oceans-actionplan.

Agora Energiewende. 2015. "The Integration Cost of Wind and Solar Power: An Overview of the Debate on the Effects of Adding Wind and Solar Photovoltaic into Power Systems." https://www.agora-energiewende.de/fileadmin2/ Projekte/2014/integrationskosten-wind-pv/Agora_Integration_Cost_Wind_ PV_web.pdf.

Atwood, T.B., R.M. Connolly, H. Almahasheer, P.E. Carnell, C.M. Duarte, C.J. Ewers Lewis, X. Irigoien, et al. 2017. "Global Patterns in Mangrove Soil Carbon Stocks and Losses." Nature Climate Change 7 (7): 523-28. doi:10.1038/ nclimate3326.

Badola, Ruchi, and Syed A. Hussain. 2005. "Valuing Ecosystem Functions: An Empirical Study on the Storm Protection Function of Bhitarkanika Mangrove Ecosystem, India." Environmental Conservation 32 (01): 85-92.

Ban, N.C., L. Eckert, M. McGreer, and A. Frid. 2017. "Indigenous Knowledge as Data for Modern Fishery Management: A Case Study of Dungeness Crab in Pacific Canada." Ecosystem Health and Sustainability 3 (8). doi:10.1080/2096412 9.2017.1379887.

Barange, M., T. Bahri, M.C.M. Beveridge, K.L. Cochrane, S. Funge-Smith, and F. Poulain. 2018. Impacts of Climate Change on Fisheries and Aquaculture: Synthesis of Current Knowledge, Adaptation and Mitigation Options. FAO Fisheries and Aquaculture Technical Paper T627. Rome: FAO. http://www.fao.org/ documents/card/en/c/19705EN/.

Barbosa, F., G. Bresciani, P. Graham, S. Nyquist, and K. Yanosek. 2020. Oil and Gas after Covid-19: The Day of Reckoning or a New Age of Opportunity? Mckinsey and Company. https://www.mckinsey.com/industries/oil-and-gas/ourinsights/oil-and-gas-after-covid-19-the-day-of-reckoning-or-a-new-age-ofopportunity. Accessed September 25.

Baskett, M.L., and L.A.K. Barnett. 2015. “The Ecological and Evolutionary Consequences of Marine Reserves." Annual Review of Ecology, Evolution, and Systematics 46 (1): 49-73. doi:10.1146/annurev-ecolsys-112414-054424.

Beasley, E., L. Schindler Murray, J. Funk, B. Lujan, K. Kasprzyk, and D. Burns. 2019. Guide to Including Nature in Nationally Determined Contributions. A Checklist of Information and Accounting Approaches for Natural Climate Solutions. https://www. conservation.org/docs/default-source/publication-pdfs/guide-to-includingnature-in-ndcs-en.pdf?Status=Master\&sfvrsn=4abd631e_2.

Because the Ocean. 2019. Ocean for Climate. Ocean-Related Measures in Climate Strategies (Nationally Determined Contributions, National Adaptation Plans, Adaptation Communications and National Policy Frameworks. https://www. becausetheocean.org/wp-content/uploads/2019/10/0cean_for_Climate_ Because_the_Ocean.pdf. 
Beck, M.W., I.J. Losada, P. Menéndez, B.G. Reguero, P. Díaz-Simal, and F. Fernández. 2018. "The Global Flood Protection Savings Provided by Coral Reefs." Nature Communications 9 (1). doi:10.1038/s41467-018-04568-z.

Bernhardt, Joanna R., and Heather M. Leslie. 2013. "Resilience to Climate Change in Coastal Marine Ecosystems." Annual Review of Marine Science 5 (January): 371-92.

Best, B.D., and P.N. Halpin. 2019. "Minimizing Wildlife Impacts for Offshore Wind Energy Development: Winning Tradeoffs for Seabirds in Space and Cetaceans in Time." PLOS ONE 14 (5). doi:10.1371/journal.pone.0215722.

Bhargava, R., D. Friess, D. Sarkar, and T. Worthington. 2019. “Mapping Areas, Understanding Causes and Estimating Impacts of Mangrove Erosion Hotspots." AGU Fall Meeting Abstracts 43 (December). http://adsabs.harvard. edu/abs/2019AGUFMGC43K1425B.

The Blue Carbon Initiative. 2020. "The Blue Carbon and Nationally Determined Contributions: Guidelines on Enhanced Action." https://www. thebluecarboninitiative.org/policy-guidance. Accessed September 25.

The Blue Carbon Initiative. n.d. "Climate Initiatives Platform." http:// climateinitiativesplatform.org/index.php/The_Blue_Carbon_Initiative. Accessed September 25, 2020.

Box, S., L. Hotra, and B. Jenks. 2018. Stemming the Tide of Coastal Overfishing: Fish Forever Program Results 2012-2017. https://www.rare.org/wp-content/ uploads/2019/02/Fish-Forever-Full-Report-July-2018.pdf.

Bryan-Brown, D.N., R.M. Connolly, D.R. Richards, F. Adame, D.A. Friess, and C.J. Brown. 2020. "Global Trends in Mangrove Forest Fragmentation." Scientific Reports 10 (1): 7117. doi:10.1038/s41598-020-63880-1.

Bulak, P., K. Proc, M. Pawlowska, A. Kasprzycka, W. Berus, B. Wojciech, and A. Bieganowski. 2020. "Biogas Generation from Insects Breeding Postproduction Wastes." Journal of Cleaner Production 244. https://doi.org/10.1016/j. jclepro.2019.118777.

Bunting, P., A. Rosenqvist, R.M. Lucas, L.-M. Rebelo, L. Hilarides, N. Thomas, A. Hardy, T. Itoh, M. Shimada, and C.M. Finlayson. 2018. "The Global Mangrove Watch-A New 2010 Global Baseline of Mangrove Extent." Remote Sensing 10 (10): 1669. doi:10.3390/rs10101669.

Burden, M., and W. Battista. 2019. Pathways for Climate-Ready Fisheries. Environmental Defense Fund, Oceans. https://www.edf.org/sites/default/ files/documents/pathwaysClimateReadyFisheries-Dec2019.pdf.

Columbia University, Socioeconomic Data and Applications Center. 2019. "Percentage of Total Population Living in Coastal Areas." https://sedac.ciesin. columbia.edu/es/papers/Coastal_Zone_Pop_Method.pdf.

Commonwealth Blue Charter Action Group on Ocean and Climate Change. 2020. "Commonwealth Blue Charter-Action Group on Oceans and Climate Change." https://bluecharter.thecommonwealth.org/action-groups/oceanclimate-change/.

Copping, A., and L. Hemery. 2020. "OES-Environmental 2020 State of the Science Report: Environmental Effects of Marine Renewable Energy Development around the World. Report for Ocean Energy Systems (OES). doi:10.2172/1632878.
Costello, C., D. Ovando, T. Clavelle, C.K. Strauss, R. Hilborn, M.C. Melnychuk, T.A. Branch, et al. 2016. "Global Fishery Prospects under Contrasting Management Regimes." Proceedings of the National Academy of Sciences 113 (18): 5125-29. doi:10.1073/pnas.1520420113.

Couce, Elena, Andy Ridgwell, and Erica J. Hendy. 2013. "Future Habitat Suitability for Coral Reef Ecosystems under Global Warming and Ocean Acidification." Global Change Biology 19 (12): 3592-606.

Das, Saudamini, and Jeffrey R. Vincent. 2009. "Mangroves Protected Villages and Reduced Death Toll during Indian Super Cyclone." Proceedings of the National Academy of Sciences 106 (18): 7357-60.

Dinerstein, E., C. Vynne, E. Sala, A.R. Joshi, S. Fernando, T.E. Lovejoy, J. Mayorga, et al. 2019. "A Global Deal For Nature: Guiding Principles, Milestones, and Targets." Science Advances 5 (4). doi:10.1126/sciadv.aaw2869.

Dinh, V.N., and E. McKeogh. 2019. "Offshore Wind Energy: Technology Opportunities and Challenges." In Proceedings of the 1st Vietnam Symposium on Advances in Offshore Engineering, edited by M.F. Randolph, D.H. Doan, A.M. Tang, M. Bui, and V.N. Dinh, 3-22. Lecture Notes in Civil Engineering. Singapore: Springer. doi:10.1007/978-981-13-2306-5_1.

Duarte, Carlos M., Iñigo J. Losada, Iris E. Hendriks, Inés Mazarrasa, and Núria Marbà. 2013. "The Role of Coastal Plant Communities for Climate Change Mitigation and Adaptation." Nature Climate Change 3 (11): 961-68.

Duke, N.C., J--0. Meynecke, S. Dittmann, A.M. Ellison, K. Anger, U. Berger, S. Cannicci, et al. 2007. "A World without Mangroves?" Science 317 (5834): 41-42. doi:10.1126/science.317.5834.41b.

EDF (Environmental Defense Fund). 2016. "Tidal Power." https://www.edf.fr/ en/the-edf-group/industrial-provider/renewable-energies/marine-energy/ tidal-power.

Energy Transitions Commission. 2018. "Mission Possible: Reaching Net-Zero Carbon Emissions from Harder-to-Abate Sectors by Mid-Century." https:// www.energy-transitions.org/publications/mission-possible/.

FAO (Food and Agriculture Organization). 2018. "The State of World Fisheries and Aquaculture 2018. Meeting the Sustainable Development Goal." Rome: FAO. https://ec.europa.eu/knowledge4policy/publication/state-worldfisheries-aquaculture-2018_en.

FA0. 2020. "The State of World Fisheries and Aquaculture 2020. Sustainability in Action." Rome: FA0. http://www.fao.org/3/ca9229en/ca9229en.pdf.

Ferrario, F., M.W. Beck, C.D. Storlazzi, F. Micheli, C.C. Shepard, and L. Airoldi. 2014. "The Effectiveness of Coral Reefs for Coastal Hazard Risk Reduction and Adaptation." Nature Communications 5 (1): 1-9.

Fransen, T., E. Northrop, K. Mogelgaard, and K. Levin. 2017. "Enhancing NDCs by 2020: Achieving the Goals of the Paris Agreement," (July). Washington, DC: World Resources Institute. https://www.wri.org/publication/ndcenhancement-by-2020.

Fransen, T., I. Sato, K. Levin, D. Waskow, D. Rich, S. Ndoko, and J. Teng. 2019. Enhancing NDCS: A Guide to Strengthening National Climate Plans by 2020. Washington, DC: World Resources Institute.

Free, C.M., J.T. Thorson, M.L. Pinsky, K.L. Oken, J. Wiedenmann, and O.P. Jensen. 2019. "Impacts of Historical Warming on Marine Fisheries Production." Science 363 (6430): 979-83. 
Friedlingstein, P., M.W. Jones, M. O'Sullivan, R.M. Andrew, J. Hauck, G.P. Peters, W. Peters, et al. 2019. "Global Carbon Budget 2019." Earth System Science Data 11 (4): 1783-838. https://doi.org/10.5194/essd-11-1783-2019.

Gaines, S.D., C. Costello, B. Owashi, T. Mangin, J. Bone, J.G. Molinos, M. Burden, et al. 2018. "Improved Fisheries Management Could Offset Many Negative Effects of Climate Change." Science Advances 4 (8). doi:10.1126/sciadv. aa01378.

Gaines, S.D., R. Cabral, C.M. Free, Y. Golbuu, R. Arnason, W. Battista, D. Bradley, et al. 2019. "The Expected Impacts of Climate Change on the Ocean Economy," Washington, DC: World Resources Institute, 56.

Gallo, N.D., D.G. Victor, and L.A. Levin. 2017. “Ocean Commitments under the Paris Agreement." Nature Climate Change 7 (11). 833-38. doi:10.1038/ nclimate3422.

Gattuso, J.P., A.K. Magnan, N. D. Gallo, D. Herr, J. Rochette, L. Vallejo, and P. Williamson. 2019. "Opportunities for Increasing Ocean Action in Climate Strategies." Policy Brief, 4.

Germany, Federal Ministry of Economics and Technology. 2020. "Kabinett Beschließt Änderung des Windenergie-auf-See-Gesetzes." https://www. bmwi.de/Redaktion/DE/Pressemitteilungen/2020/20200603-kabinettbeschliesst-aenderung-des-windenergie-auf-see-gesetzes.html.

Giri, C., E. Ochieng, L.L. Tieszen, Z. Zhu, A. Singh, T. Loveland, J. Masek, and N. Duke. 2011. "Status and Distribution of Mangrove Forests of the World Using Earth Observation Satellite Data." Global Ecology and Biogeography 20 (1):154-59. doi:10.1111/j.1466-8238.2010.00584.x.

Goldberg, L., D. Lagomasino, and T. Fatoyinbo. 2019. "Mapping the Global Drivers of Mangrove Loss and Vulnerability." In Proceedings of the Fifth International Mangrove Macrobenthos and Management Meeting, Singapore, July $1-5$.

Government of Australia. 2015. "Intended Nationally Determined Contribution."

Government of Belize. 2015. Intended Nationally Determined Contribution. https://www4.unfccc.int/sites/submissions/INDC/Published\%20Documents/ Belize/1/Belize\%20INDCS.pdf.

Government of Chile. 2020. Nationally Determined Contribution (NDC). https://www4.unfccc.int/sites/ndcstaging/PublishedDocuments/Chile\%20 First/Chile\%27s_NDC_2020_english.pdf.

Government of Fiji. 2015. Intended Nationally Determined Contribution. https://www4.unfccc.int/sites/submissions/INDC/Published\%20Documents/ Fiji/1/FIII_iNDC_Final_051115.pdf.

Government of Haiti. 2015. Intended Nationally Determined Contribution. https://www4.unfccc.int/sites/submissions/INDC/Published\%20Documents/ Haiti/1/CPDN_Republique\%20d'Haiti.pdf.

Government of Japan. 2020. Nationally Determined Contribution (NDC). https://www4.unfccc.int/sites/ndcstaging/PublishedDocuments/ Japan\%20First/SUBMISSION\%200F\%20JAPAN\%27S\%20NATIONALLY\%20 DETERMINED\%20CONTRIBUTION\%20(NDC).PDF.

Government of the Kingdom of Tonga. 2015. Intended Nationally Determined Contribution. https://www4.unfccc.int/sites/ndcstaging/ PublishedDocuments/Tonga\%20First/Tonga\%20INDC.pdf.
Government of Madagascar. 2015. Intended Nationally Determined Contribution. https://www4.unfccc.int/sites/submissions/INDC/ Published\%20Documents/Madagascar/1/Madagascar\%20INDC\%20Eng.pdf.

Government of the Republic of Marshall Islands. 2015. Intended Nationally Determined Contribution. https://www4.unfccc.int/sites/submissions/ INDC/Published\%20Documents/Marshall\%20Islands/1/150721\%20RMI\%20 INDC\%20JULY\%202015\%20FINAL\%20SUBMITTED.pdf.

Government of Sri Lanka. 2015. Intended Nationally Determined Contribution. https://www4.unfccc.int/sites/ndcstaging/PublishedDocuments/Sri\%20 Lanka\%20First/NDCs\%20of\%20Sri\%20Lanka.pdf.

Government of the United Kingdom. 2018. "Clean Growth Strategy: Leading the Way to a Low Carbon Future." GOV.UK. https://www.gov.uk/government/ publications/clean-growth-strategy.

Government of the United Kingdom. 2019a. "Contracts for Difference (CfD) Allocation Round 3: Results." GOV.UK. https://www.gov.uk/government/ publications/contracts-for-difference-cfd-allocation-round-3-results.

Government of the United Kingdom. 2019b. "Offshore Wind: Sector Deal." GOV.UK. https://www.gov.uk/government/publications/offshore-windsector-deal. Accessed September 25, 2020.

Government of the United Kingdom. 2020. "New Plans to Make UK World Leader in Green Energy." GOV.UK. https://www.gov.uk/government/news/ new-plans-to-make-uk-world-leader-in-green-energy.

Government of Viet Nam. 2015. Intended Nationally Determined Contribution. https://www4.unfccc.int/sites/ndcstaging/PublishedDocuments/Viet\%20 Nam\%20First/VIETNAM\%27S\%20INDC.pdf.

Government of Viet Nam. 2020. Nationally Determined Contribution (NDC). https://www4.unfccc.int/sites/ndcstaging/PublishedDocuments/Chile\%20 First/Chile\%27s_NDC_2020_english.pdf.

The Green Climate Fund. 2018. "Enhancing Climate Resilience of India's Coastal Communities." https://www.greenclimate.fund/document/ enhancing-climate-resilience-indias-coastal-communities.

Greer, K., D. Zeller, J. Woroniak, A. Coulter, M. Winchester, M.L.D. Palomares, and D. Pauly. 2019. "Global Trends in Carbon Dioxide ( $\left.\mathrm{CO}_{2}\right)$ Emissions from Fuel Combustion in Marine Fisheries from 1950 to 2016." Marine Policy 107 (September): 103382. doi:10.1016/j.marpol.2018.12.001.

Grimm, D., I. Barkhorn, D. Festa, K. Bonzon, J. Boomhower, V. Hovland, and J. Blau. 2012. "Assessing Catch Shares' Effects Evidence from Federal United States and Associated British Columbian Fisheries." Marine Policy 36 (3). https://doi.org/10.1016/j.marpol.2011.10.014.

The Guardian. 2016. “World's First Large-Scale Tidal Energy Farm Launches in Scotland." The Guardian, September 12, sec. UK news. https://www. theguardian.com/uk-news/2016/sep/12/worlds-first-large-scale-tidalenergy-farm-launches-scotland.

Gustavsson, J., C. Cederberg, and S. Ulf. 2011. Global Food Losses and Food Waste. Rome: Food and Agriculture Organization. http://www.fao.org/3/ $\mathrm{mb060e} / \mathrm{mb} 060 \mathrm{e} 00 . \mathrm{htm}$.

Gutiérrez, N.L., R. Hilborn, and O. Defeo. 2011. "Leadership, Social Capital and Incentives Promote Successful Fisheries." Nature 470 (7334): 386-89. doi:10.1038/nature09689. 
Hale, L., P.V. Ejik, M. Hatziols, N. Davidson, R. Chacko, and C. Toropova. 2009. "Ecosystem-Based Adaptation to Climate Change in Coastal and Marine Areas." IOP Conference Series: Earth and Environmental Science 6 (35): 352006. doi:10.1088/1755-1307/6/35/352006.

Hamilton, S.E., and D. Casey. 2016. "Creation of a High Spatio-Temporal Resolution Global Database of Continuous Mangrove Forest Cover for the 21st Century (CGMFC-21)." Global Ecology and Biogeography 25 (6): 729-38. doi:10.1111/geb.12449.

Hamilton, S.E., and D.A. Friess. 2018. "Global Carbon Stocks and Potential Emissions Due to Mangrove Deforestation from 2000 to 2012." Nature Climate Change 8 (3): 240-44. doi:10.1038/s41558-018-0090-4.

Haugan, P.M., L.A. Levin, D. Amon, M. Hemer, H. Lily, and F.G. Nielsen. 2020. "What Role for Ocean-Based Renewable Energy and Deep Seabed Minerals in a Sustainable Future?" Washington, DC: World Resources Institute. www. oceanpanel.org/blue-papers/ocean-energy-and-mineral-sources.

Henriksson, Patrik J.G., Jeroen B. Guinée, René Kleijn, and Geert R. de Sno0. 2012. "Life Cycle Assessment of Aquaculture Systems - A Review of Methodologies." The International Journal of Life cycle Assessment 17 (3): 304-13.

Herr, D., and E. Landis. 2016. Coastal Blue Carbon Ecosystems. Opportunities for Nationally Determined Contributions. Policy Brief. http://www. mangrovealliance. org/wp-content/uploads/2017/08/BC-NDCs_FINAL.pdf.

Hilborn, R., and C. Costello. 2018. "The Potential for Blue Growth in Marine Fish Yield, Profit and Abundance of Fish in the Ocean." Marine Policy 87 (January): 350-55. doi:10.1016/j.marpol.2017.02.003.

Hilborn, R., R.O. Amoroso, C.M. Anderson, J.K. Baum, T.A. Branch, C. Costello, C.L. de Moor, et al. 2020. "Effective Fisheries Management Instrumental in Improving Fish Stock Status." Proceedings of the National Academy of Sciences 117 (4): 2218-24. doi:10.1073/pnas.1909726116.

Hoegh-Guldberg. O., K. Caldeira, T. Chopin, S. Gaines, P. Haugan, M. Herner, J. Howard, et al. 2019. "The Ocean as a Solution to Climate Change: Five Opportunities for Action." Washington, DC: World Resources Institute. http:// www.oceanpanel.org/climate.

Holland, E., P. Nuttall, A. Newell, B. Prasad, J. Veitayaki, A. Bola, and J. Kaitu'u. 2014. "Connecting the Dots: Policy Connections between Pacific Island Shipping and Global $\mathrm{CO}_{2}$ and Pollutant Emission Reduction." Carbon Management 5 (1): 93-105. doi:10.4155/cmt.13.78.

Hollowed A.B., M. Barange, R.J. Beamish, K. Brander, K. Cochrane, K. Drinkwater, M.G.G. Foreman, et al. 2013. "Projected Impacts of Climate Change on Marine Fish and Fisheries." ICES Journal of Marine Science 70, 5 (September): 1023-37. https://academic.oup.com/icesjms/ article/70/5/1023/645653.

Holsman, K.K., A.C. Haynie, A.B. Hollowed, J.C.P. Reum, K. Aydin, A.J. Hermann, W. Cheng, et al. 2020. "Ecosystem-Based Fisheries Management Forestalls Climate-Driven Collapse." Nature Communications 11 (1): 4579. doi:10.1038/s41467-020-18300-3.

Holsman, K., J. Samhouri, G. Cook, E. Hazen, E. Olsen, M. Dillard, S. Kasperski, et al. 2017. "An Ecosystem-Based Approach to Marine Risk Assessment." Ecosystem Health and Sustainability 3 (1): e01256. doi:10.1002/ehs2.1256.
Howard, J., S. Hoyt, K. Isensee, M. Telszewski, and E. Pidgeon. 2014. "Coastal Blue Carbon: Methods for Assessing Carbon Stocks and Emission Factors in Mangroves, Tidal Salt Marshes, and Seagrass Meadows." Arlington, VA: Conservation International, Intergovernmental Oceanographic Commission of UNESCO, International Union for Conservation of Nature. https://estuaries. org/resource-library/coastal-blue-carbon-methods-for-assessing-carbonstocks-and-emission-factors-in-mangroves-tidal-salt-marshes-and-seagrassmeadows/.

Hutchison, J., A. Manica, R. Swetnam, A. Balmford, and M. Spalding. 2014. "Predicting Global Patterns in Mangrove Forest Biomass." Conservation Letters 7 (3): 233-40. doi:10.1111/conl.12060.

ICCT (International Council on Clean Transportation). 2015. "Global GHG Emissions 2013-2015." https://www.theicct.org/sites/default/ files/publications/Global-shipping-GHG-emissions-2013-2015_ICCTReport_17102017_vF.pdf.

IEA (International Energy Agency). 2017. "Energy Technology PerspectivesTopics." https://www.iea.org/topics/energy-technology-perspectives.

IEA. 2019. "Global Energy and CO, Status Report 2019_Analysis." https:// www.iea.org/reports/global-energy-co2-status-report-2019.

IEA. 2020a. "Global Energy Review 2020." https://www.iea.org/reports/ global-energy-review-2020. Accessed October 6.

IEA. 2020b. "World Energy Investment 2020." https://www.iea.org/reports/ world-energy-investment-2020. Accessed October 6.

International Climate Initiative (IKI), 2020. "Fishing for Climate Resilience: Empowering Vulnerable, Fisheries Dependent Communities Adopt EcosystemBased-Adaptation Measures to Secure Food and Livelihoods." https://www. international-climate-initiative.com/en/details/project/fishing-for-climateresilience-empowering-vulnerable-fisheries-dependent-communities-adoptecosystembasedadaptation-measures-to-secure-food-and-livelihoods-19_ II_162-3015. Accessed October 29, 2020.

IPCC (Intergovernmental Panel on Climate Change). 2012: "Managing the Risks of Extreme Events and Disasters to Advance Climate Change Adaptation." A Special Report of Working Groups I and II of the Intergovernmental Panel on Climate Change," edited by C.B. Field, V. Barros, T.F. Stocker, D. Qin, D.J. Dokken, K.L. Ebi, M.D. Mastrandrea, et al. Cambridge, UK: Cambridge University Press.

IPCC. 2014. "2013 Supplement to the 2006 IPCC Guidelines for National Greenhouse Gas Inventories: Wetlands," edited by T. Hiraishi, T. Krug, K. Tanabe, N. Srivastava, J. Baasansuren, M. Fukuda, and T. Troxler. Geneva: IPCC. https://www.ipcc.ch/publication/2013-supplement-to-the-2006-ipccguidelines-for-national-greenhouse-gas-inventories-wetlands/.

IPCC. 2018. "Global Warming of $1.5^{\circ} \mathrm{C}$. An IPCC Special Report on the Impacts of Global Warming of $1.5^{\circ} \mathrm{C}$ above Pre-industrial Levels and Related Global Greenhouse Gas Emission Pathways, in the Context of Strengthening the Global Response to the Threat of Climate Change, Sustainable Development, and Efforts to Eradicate Poverty," edited by V. Masson-Delmotte, P. Zhai, H.-O. Pörtner, D. Roberts, J. Skea, P.R. Shukla, A. Pirani, et al.

IPCC. 2019. IPCC Special Report on the Ocean and Cryosphere in a Changing Climate. Geneva: IPCC. 
IRENA (International Renewable Energy Agency). 2018a. "Global Energy Transformation: A Roadmap to 2050." https:irena.org/Publications/2019/Apr/ Global-Energy-Transformation-A-Roadmap-to-2050-2019Edition.

IRENA. 2018b. "Offshore Wind Investment, Policies and Job Creation: Review of Key Findings for G7 Ministerial Meetings." Halifax, Canada: IRENA, 16.

IRENA. 2019. "Future of Wind: Deployment, Investment, Technology, Grid Integration and Socio-Economic Aspects." (A Global Energy Transformation Paper. Abu Dhabi: IRENA.

IUCN (International Union for Conservation of Nature). 2016. IUCN Resolution. https://portals.iucn.org/library/sites/library/files/resrecfiles/WCC_2016_ RES_050_EN.pdf.

IUCN. 2017a. "Marine Protected Areas and Climate Change." IUCN. https:// www.iucn.org/resources/issues-briefs/marine-protected-areas-and-climatechange.

IUCN. 2017b. "Equity and Justice in PA Conservation." IUCN. https://www. iucn.org/theme/protected-areas/our-work/governance-equity-and-rights/ equity-and-justice-pa-conservation.

IYOR (International Year of the Reef). 2018a. "Insuring Nature to Ensure a Resilient Future: Coastal Zone Management Trust." IYOR 2018 (blog). https://www.iyor2018.org/wp-content/uploads/2018/03/TNCCoastalManagementTrust_Infographic_04.pdf.

IYOR. 2018b "Launch of the Coastal Zone Management Trust." IYOR 2018 (blog). https://www.iyor2018.org/news/launch-coastal-zone-management-trust/.

Jardine, S.L., and J.V. Siikamäki. 2014. "A Global Predictive Model of Carbon in Mangrove Soils." Environmental Research Letters 9 (10): 104013. doi:10.1088/1748-9326/9/10/104013.

Kousky, C., and S. Light. 2019. "Insuring Nature." Duke Law Journal 69 (2): 323-76. https://scholarship.law.duke.edu/dlj/vol69/iss2/2.

Kroeker, K.J., M.H. Carr, P.T. Raimondi, J.E. Caselle, L. Washburn, S.R. Palumbi, J.A. Barth, et al. 2019. "PLANNING FOR CHANGE: Assessing the Potential Role of Marine Protected Areas and Fisheries Management Approaches for Resilience Management in a Changing Ocean." Oceanography 32 (3): 116-25. https://www.jstor.org/stable/26760090.

Levin, K., J. Finnegan, D. Rich, and P. Bhatia. 2014. "GHG Protocol: Mitigation Goal Standard." Washington, DC: World Resources Institute. https:// ghgprotocol.org/mitigation-goal-standard.

Light, S., and C. Kousky. n.d. "Insuring Ecosystems to Ensure Climate Resilience." Risk Management and Decision Processes Center (blog). https:// riskcenter.wharton.upenn.edu/dimate-risk-solutions-2/insuring-ecosystemsto-ensure-climate-resilience/. Accessed September 25, 2020.

Losada, I. J., P. Menéndez, A. Espejo, S. Torres, P. Díaz-Simal, S. Abad, M. W. Beck, et al. 2018. "The Global Value of Mangroves for Risk Reduction." Technical Report. Berlin: The Nature Conservancy.

Love, D.C., J.P. Fry, M.C. Milli, and R.A. Neff. 2015. "Wasted Seafood in the United States: Quantifying Loss from Production to Consumption and Moving toward Solutions." Global Environmental Change 35 (November):116-24. doi:10.1016/j.gloenvcha.2015.08.013.

Maersk. 2018. "Maersk Sets Net Zero CO, Emission Target by 2050." The Maritime Executive. https://www.maritime-executive.com/article/maersk-setsnet-zero-coz-emission-target-by-2050.
Manouchehrinia, B., Z. Dong, and T.A. Gulliver, C. Gough, and S. Molloy. 2018. "Emission and Life-Cycle Cost Analysis of Hybrid and Pure Electric Propulsion Systems for Fishing Boats." Journal of Ocean Technology 13 (2): 64-87.

Martin, E., C. Perine, V. Lee, and J. Ratcliffe. 2018. “Decentralized Governance and Climate Change Adaptation: Working Locally to Address Community Resilience Priorities." In Theory and Practice of Climate Adaptation, edited by F. Alves, W. Leal Filho, and U. Azeiteiro, 3-22. Springer International Publishing. doi:10.1007/978-3-319-72874-2_1.

Maynard, J., D. Tracey, G.J. Williams, D.A. Andradi-Brown, G. Grill, M. Thieme, and G.N. Ahmadia. 2019. Mangrove Cover Change between 1996 and 2016 Near River-Ocean Outlets: A Global Analysis to Identify Priority Rivers for Conservation. Washington, DC: World Wildlife Fund. doi:10.6084/m9.figshare.8094245.v2.

McLeod, E., R. Salm, A. Green, and J. Almany. 2009. "Designing Marine Protected Area Networks to Address the Impacts of Climate Change." Frontiers in Ecology and the Environment 7 (7): 362-70. doi:10.1890/070211.

MCST (Micronesian Center for Sustainable Transport). 2020. "MCST_Pacific Blue Shipping Partnership." https://mcst-rmiusp.org/index.php/projects/ current-projects/pacific-blue-shipping-partnership.

Melnychuk, M.C., T.E. Essington, T.A. Branch, S.S. Heppell, O.P. Jensen, J.S. Link, S.J.D. Martell, et al. 2012. "Can Catch Share Fisheries Better Track Management Targets?" Fish and Fisheries 13 (3): 267-90. doi:10.1111/j.14672979.2011.00429.x.

Merwin, A., S.R. Cooley, J.D. McBee, G. Taraska, A. Zivian, and C. Robbins. 2020. "Ocean and Climate Discussion Series: 'Climate-Smart' Marine Protected Areas for Mitigation and Adaptation Policy." Ocean Conservancy, June. https:// oceanconservancy.org/wp-content/uploads/2020/07/Climate-Smart-MPAsBrief_FINAL_7_1_update.pdf. Accessed October 22, 2020.

Mexico, SEMARNAT-INECC (Ministry of Environment and Natural ResourcesNational Institute of Ecology and (limate Change). 2016. Mexico's Climate Change Mid-Century Strategy." Mexico City: SEMARNAT and INECC.

Miller, K., A. Charles, M. Barange, K. Brander, V.F. Gallucci, M.A. Gasalla, A. Khan, et al. 2010. "Climate Change, Uncertainty, and Resilient Fisheries: Institutional Responses through Integrative Science." Progress in Oceanography 87 (1): 338-46. doi:10.1016/j.pocean.2010.09.014.

Murphy, A. 2018. "Aviation and Shipping Emissions and National Climate Pledges: Ensuring Paris Pledges Are Truly Economy-Wide." Brussels: Transport and Environment. https://www.transportenvironment.org/publications/ aviation-and-shipping-emissions-and-national-climate-pledges. Accessed September 25, 2020.

NOAA (National Oceanic and Atmospheric Administration). n.d. "Coral Reef Ecosystems." Washington, DC: U.S. Department of Commerce, National Oceanic and Atmospheric Administration. https://www.noaa.gov/education/ resource-collections/marine-life/coral-reef-ecosystems. Accessed September $25,2020$.

Norway, Ministry of Climate and Environment. 2019. “The Government's Action Plan for Green Shipping." https://www.regjeringen.no/en/ dokumenter/the-governments-action-plan-for-green-shipping/id2660877/.

NPR (National Public Radio). n.d. "Seychelles Finds a Novel Way to Swap Its Debt for Marine Protections." NPR. https://www.npr.org/sections/thetwoway/2018/02/23/588273709/seychelles-finds-a-novel-way-to-swap-its-debtfor-marine-protections. Accessed September 25, 2020. 
NRDC (Natural Resources Defense Council) and New Climate Institute. 2018. "Realizing the Promise of Paris: Roadmap to a Safer Climate." https://www. nrdc.org/resources/realizing-promise-paris-roadmap-safer-climate.

OES (Ocean Energy Systems). 2017. "OES Vision for International Deployment of Ocean Energy." https://www.ocean-energy-systems.org/news/oes-visionfor-international-deployment-of-ocean-energy/.

Olmer, N., B. Comer, B. Roy, X. Mao, and D. Rutherford. 2013. "Greenhouse Gas Emissions from Global Shipping, 2013-2015." International Council on Clean Transportation, 38.

Ørsted. 2019. "Ørsted Summary 2019. Annual Report and Sustainability Report." https://orsted.com/-/media/annual2019/AR19-EN-Summary-2019. pdf.

Parker, R.W.R., K. Hartmann, B.S. Green, C. Gardner, and R.A. Watson. 2015. "Environmental and Economic Dimensions of Fuel Use in Australian Fisheries." Journal of Cleaner Production 87 (January): 78-86. doi:10.1016/j. jclepro.2014.09.081.

Parker, R.W.R., J.L. Blanchard, C. Gardner, B.S. Green, K. Hartmann, P.H. Tyedmers, and R.A. Watson. 2018. "Fuel Use and Greenhouse Gas Emissions of World Fisheries." Nature Climate Change 8 (4): 333-37. doi:10.1038/s41558018-0117-x.

Pelletier, N., P. Tyedmers, U. Sonesson, A. Scholz, F. Ziegler, A. Flysjo, S. Kruse, et al. 2009. "Not All Salmon Are Created Equal: Life Cycle Assessment (LCA) of Global Salmon Farming Systems." Environ. Sci. Technol. 43 (23): 8730-36.

Pelletier, N., and P. Tyedmers. 2010. "Forecasting Potential Global Environmental Costs of Livestock Production 2000-2050." Proceedings of the National Academy of Sciences 107 (43): 18371-74.

Pendleton, L., D.C. Donato, B.C. Murray, S. Crooks, W.A. Jenkins, S. Sifleet, C. Craft, et al. 2012. "Estimating Global 'Blue Carbon' Emissions from Conversion and Degradation of Vegetated Coastal Ecosystems." PLOS ONE 7 (9): e43542. doi:10.1371/journal.pone.0043542.

Picourt, L. C. de Courcy, V. Brun. 2017. "Measuring Progress on Ocean and Climate Initiatives: An Action-Oriented Report." Ocean Climate Platform. https://ocean-climate.org/?lang=en.

Pinsky, M.L., and N. Mantua. 2014. “Emerging Adaptation Approaches for Climate-Ready Fisheries Management." Oceanography 27 (4): 146-59. doi:10.5670/oceanog.2014.93.

Pinsky, M.L., G. Reygondeau, R. Caddell, J. Palacios-Abrantes, J. Spijkers, and W.W.L. Cheung. 2018. "Preparing Ocean Governance for Species on the Move." Science 360 (6394): 1189-91. doi:10.1126/science.aat2360.

Poore, I., and T. Nemecek. 2018. "Reducing Food's Environmental Impacts through Producers and Consumers." Science 360 (6392): 987-92. https:// science.sciencemag.org/content/360/6392/987.

Poseidon Principles. n.d. A Global Framework for Responsible Ship Finance. https://www.poseidonprinciples.org/.

Punt, A.E., T. A'mar, N.A. Bond, D.S. Butterworth, C.L. de Moor, J.A.A. De Oliveira, M.A. Haltuch, et al. 2014. "Fisheries Management under Climate and Environmental Uncertainty: Control Rules and Performance Simulation." ICES Journal of Marine Science 71 (8): 2208-20. doi:10.1093/icesjms/fst057.
Punt, A.E., D.S. Butterworth, C.L. de Moor, J.A.A.D. Oliveira, and M. Haddon. 2016. "Management Strategy Evaluation: Best Practices." Fish and Fisheries 17 (2): 303-34. doi:10.1111/faf.12104.

Reddy, S.W. 2016. "Local Fishing Groups Hold the Tools for Sustainable Fishing, but Need the Strength of Property Rights." Cool Green Science. April 27. https://blog.nature.org/science/2016/04/27/local-fishing-tools-sustainablestrength-property-rights/.

Rich, D., P. Bhatia, J. Finnegan, K. Levin, and A. Mitra. 2014. GHG Protocol: Policy and Action Standard: An Accounting and Reporting Standard for Estimating the Greenhouse Gas Effects of Policies and Actions. Washington, DC: World Resources Institute. https://www.wri.org/publication/policy-and-action-standard.

Robb, D.H.F., M. MacLeod, M. R. Hasan, and D. Soto. 2017. "Greenhouse Gas Emissions from Aquaculture: A Life Cycle Assessment of Three Asian Systems." FAO Fisheries and Aquaculture Technical Paper 609.

Roberts, C.M., B.C. O'Leary, D.J. McCauley, P.M. Cury, C.M. Duarte, J. Lubchenco, D. Pauly, et al. 2017. "Marine Reserves Can Mitigate and Promote Adaptation to Climate Change." Proceedings of the National Academy of Sciences 114 (24): 6167-75. doi:10.1073/pnas.1701262114.

Rovai, A.S., R.R. Twilley, E. Castañeda-Moya, P. Riul, M. Cifuentes-Jara, M. Manrow-Villalobos, P.A. Horta, et al. 2018. "Global Controls on Carbon Storage in Mangrove Soils." Nature Climate Change 8: 534-38. https://doi. org/10.1038/s41558-018-0162-5.

Sanderman, J., T. Hengl, G. Fiske, K. Solvik, M.F. Adame, L. Benson, J.J. Bukoski, et al. 2018. "A Global Map of Mangrove Forest Soil Carbon at 30। hspace0.167emm Spatial Resolution." Environmental Research Letters 13 (5): 055002. doi:10.1088/1748-9326/aabelc.

Sarker, Pallab K., Anne R. Kapuscinski, Ashley Y. Bae, Emily Donaldson, Alexander J. Sitek, Devin S. Fitzgerald, and Oliver F. Edelson. 2018. "Towards Sustainable Aquafeeds: Evaluating Substitution of Fishmeal with LipidExtracted Microalgal Co-product (Nannochloropsis oculata) in Diets of Juvenile Nile Tilapia (Oreochromis niloticus)." PLoS One 13 (7): e0201315.

Searchinger, T., R. Waite, C. Hanson, J. Ranganathan, P. Dumas, and E. Matthews. 2018. Creating a Sustainable Food Future: A Menu of Solutions to Feed Nearly 10 Billion People by 2050 (Synthesis Report). Washington, DC: World Resources Institute. https://www.wri.org/publication/creating-sustainablefood-future.

Seddon, N., H. Reid, E. Barrow, C. Hicks, X. Hou-Jones, V. Kapos, A.R. Rizvi, et al. 2016. "Ecosystem-Based Approaches to Adaptation: Strengthening the Evidence and Informing Policy. Research Overview and Overarching Questions." Background Paper. London: International Institute for Environment and Development (IIED), May 19. https://www.iucn.org/theme/ ecosystem-management/our-work/ecosystem-based-adaptation-andclimate-change/eba-strengthening-evidence-and-informing-policy.

Sievers, M., C.J. Brown, V.J.D. Tulloch, R.M. Pearson, J.A. Haig, M.P. Turschwell, and R.M. Connolly. 2019. "The Role of Vegetated Coastal Wetlands for Marine Megafauna Conservation." Trends in Ecology and Evolution 34 (9): 807-17. doi:10.1016/j.tree.2019.04.004.

Siikamäki, J., J.N. Sanchirico, and S.L. Jardine. 2012. "Global Economic Potential for Reducing Carbon Dioxide Emissions from Mangrove Loss." Proceedings of the National Academy of Sciences of the United States of America 109 (36): 14369-74. doi:10.1073/pnas.1200519109. 
Simard, M., L. Fatoyinbo, C. Smetanka, V.H. Rivera-Monroy, E. CastañedaMoya, N. Thomas, and T. Van der Stocken. 2019. "Mangrove Canopy Height Globally Related to Precipitation, Temperature and Cyclone Frequency." Nature Geoscience 12 (1): 40-45. doi:10.1038/s41561-018-0279-1.

Spalding, M., L. Burke, S.A. Wood, J. Ashpole, J. Hutchison, and P. zu Ermgassen. 2017. "Mapping the Global Value and Distribution of Coral Reef Tourism." Marine Policy 82 (August): 104-13. doi:10.1016/j. marpol.2017.05.014.

Springmann, M., M. Clark, D. Mason-D'Croz, K. Wiebe, B.L. Bodirsky, L. Lassaletta, W. de Vries, et al. 2018. "Options for Keeping the Food System within Environmental Limits." Nature 562 (7728): 519-25. doi:10.1038/ s41586-018-0594-0.

Strong, M.F. 1986. World Resources Institute 1986. Washington, DC: World Resources Institute Publications. https://worldveg.tind.io/record/3760/.

SwissReGroup. n.d. "Designing a New Type of Insurance to Protect the Coral Reefs, Economies and the Planet." https://www.swissre.com/our-business/ public-sector-solutions/thought-leadership/new-type-of-insurance-toprotect-coral-reefs-economies.html. Accessed September 25, 2020.

Tang, W., M. Zheng, X. Zhao, J. Shi, J. Yang, and C.C. Trettin. 2018. “Big Geospatial Data Analytics for Global Mangrove Biomass and Carbon Estimation." Sustainability 10 (2): 472. doi:10.3390/su10020472.

Tercek, M. 2018. "Business to the Rescue: Insurance for Reef Restoration." https://www.forbes.com/sites/marktercek/2018/03/08/business-to-therescue-insurance-for-reef-restoration/\#4e9a941d3e0c.

Thiele, T., G. Alleng, A. Biermann, E. Corwin, S. Crooks, O. Fieldhouse, and J. Zeitlberger. 2020. "Blue Infrastructure Finance: A New Approach Integrating Nature-Based Solutions for Coastal Resilience." Conservation Finance Alliance. https://www.conservationfinancealliance.org/what-were-reading/2020/5/7/ blue-infrastructure-finance-a-new-approach-integrating-nature-basedsolutions-for-coastal-resilience. Accessed September 25.

TNC (The Nature Conservancy). 2019a. "Blue Bonds: An Audacious Plan to Save the World's Oceans." https://tnc.app.box.com/s/4is8gwjy3011124vxwh mu53064k08jc8.

TNC. 2019b. "The Nature Conservancy Applauds Government of Quintana Roo for Purchasing the World's First Coral Reef Insurance Policy." https://www. nature.org/en-us/newsroom/quintana-roo-worlds-first-coral-reef-insurance/.

Twilley, R.R., R.H. Chen, and T. Hargis. 1992. "Carbon Sinks in Mangroves and Their Implications to Carbon Budget of Tropical Coastal Ecosystems." In Natural Sinks of $\mathrm{CO}_{2}$ : Palmas del Mar, Puerto Rico, 24-27 February 1992, edited by J. Wisniewski and A.E. Lugo, 265-88. Dordrecht: Springer Netherlands. doi:10.1007/978-94-011-2793-6_15.

Twilley, R.R., A.S. Rovai, and P. Riul. 2018. "Coastal Morphology Explains Global Blue Carbon Distributions." Frontiers in Ecology and the Environment 16 (9): 503-8. doi:10.1002/fee.1937.

UNCTAD (United Nations Conference on Trade And Development). 2018. Review of Maritime Transport 2018. New York and Geneva: United Nations.

UNCTAD. 2020. "The COVID-19 Pandemic and the Blue Economy: New Challenges and Prospects for Recovery and Resilience." Green Growth Knowledge Platform. May 13. https://www.greengrowthknowledge.org/ research/covid-19-pandemic-and-blue-economy-new-challenges-andprospects-recovery-and-resilience.
UNDP in the Pacific. n.d. "New Partnership Looks to Create Pacific-Wide Microinsurance Solution for Coastal Fisheries Sector." https://www.pacific. undp.org/content/pacific/en/home/presscenter/pressreleases/2018/02/01/ new-partnership-looks-to-create-pacific-wide-microinsurance-solution-forcoastal-fisheries-sector.html. Accessed September 25, 2020.

UNFCCC (United Nations Framework Convention on Climate Change). 2015. "Paris Agreement." https://unfccc.int/sites/default/files/ english_paris_ agreement.pdf.

UNFCCC. 2018. "COP Decision 1/CP.24." https://unfccc.int/sites/default/ files/ resource/10a1.pdf.

UN Sustainable Development Knowledge Platform. 2017. "Factsheet: People and Oceans." The Ocean Conference, New York, June 5-9. https://www. un.org/sustainabledevelopment/wp-content/uploads/2017/05/0cean-factsheet-package.pdf.

van Marlen, B. 2009. “Energy Saving in Fisheries (ESIF).” https://ec.europa. eu/fisheries/sites/fisheries/files/docs/publications/energy_saving_en.pdf.

Wiebes, E. 2018. "Offshore Wind Energy Roadmap 2030." https://english. rvo.nl/sites/default/files/2018/03/Brief\%20routekaart\%20windenergie\%20 op\%20zee\%202024-2030\%20-\%20EN.pdf.

Winther, J.-G., M. Dai, F. Douvere, L. Fernandes, P. Halpin, A. Hakon Hoel, M.A. Juinio-Meñez, et al. 2020. "Integrated Ocean Management." High-Level Panel for a Sustainable Ocean Economy, Blue Paper. Washington, DC: World Resources Institute. https://oceanpanel.org/blue-papers.

World Bank. 2018. "Seychelles Launches World's First Sovereign Blue Bond." Washington, DC: World Bank. doi:10/29/seychelles-launches-worlds-firstsovereign-blue-bond.

World Bank. 2019. "Going Global: Expanding Offshore Wind to Emerging Markets." World Bank's Energy Sector Management Assistance Program (ESMAP). https://www.esmap.org/going_global_offshore_wind.

Worthington, T.A., D.A. Andradi-Brown, R. Bhargava, C. Buelow, P. Bunting, C. Duncan, L. Fatoyinbo, et al. 2020. "Harnessing Big Data to Support the Conservation and Rehabilitation of Mangrove Forests Globally." One Earth 2 (5): 429-43. doi:10.1016/j.oneear.2020.04.018.

Worthington, Thomas \& Mark Spalding. 2018. "Mangrove Restoration Potential: A global map highlighting a critical opportunity." 10.17863/ CAM.39153. https://www.repository.cam.ac.uk/handle/1810/292000."

WRI (World Resources Institute). 2020. "Climate Watch: 2020 NDC Tracker." https://www. climatewatchdata.org/2020-ndc-tracker.

Ziegler, F., and S. Hornborg. 2014. "Stock Size Matters More than Vessel Size: The Fuel Efficiency of Swedish Demersal Trawl Fisheries 2002-2010." Marine Policy 44 (February): 72-81. doi:10.1016/j.marpol.2013.06.015. 


\section{ACKNOWLEDGMENTS}

We are pleased to acknowledge our institutional strategic partners, which provide core funding to WRI: Netherlands Ministry of Foreign Affairs, Royal Danish Ministry of Foreign Affairs, and Swedish International Development Cooperation Agency. Funding for this analysis is provided by IKEA Foundation.

We are also pleased to acknowledge the Federal Ministry for Economic Cooperation and Development of Germany (BMZ), which provided funding for the project as a contribution to the NDC Partnership. UNDP is pleased to acknowledge support from BMU, $B M Z$, the European Union, and Spain (AECID), in contribution to the NDC Partnership.

The authors would like to thank the following people for their review and feedback: Sue Biniaz (United Nations Foundation); Merrick Burden (Environmental Defense Fund [EDF]); Julio Cordano (Ministry of Foreign Affairs, Chile); Paolo Domondon (Rare); Courtney Durham (PEW Charitable Trusts); Taryn Fransen (World Resources Institute [WRI]); Nicola Frost (WRI); Tom Hickey (PEW Charitable Trusts);
Andrew Hudson (United Nations Development Programme [UNDP]); Norma Hutchinson (WRI); Kristin Kleisner (EDF); Manaswita Konar (WRI); Anthony Mansell (Climate Advisers); Alex Perera (WRI); Joanna Post (United Nations Framework Convention on Climate Change [UNFCCC]); Angelique Pouponneau (Seychelles' Conservation and Climate Adaptation Trust [SeyCCAT]); Nikesh Prakash (Deutsche Gesellschaft für Internationale Zusammenarbeit [GIZ], Fiji); Kushaal Raj (Fiji, Ministry of Economy); John Verdieck (The Nature Conservancy $[T N C]) ;$ Arief Wijaya (WRI Indonesia); and Vositha Wijenayake (Climate Action Network [CAN]).

While our colleagues were very generous with time and input, this working paper reflects the views of the authors alone.

The authors would also like to thank Tim Constien and Mary Levine for administrative support and Romain Warnault, Emily Matthews, Emilia Suarez, and Shazia Amin for supporting the editing and publication process. 


\section{ABOUT THE AUTHORS}

Eliza Northrop is a Senior Associate and the Policy Lead for the Sustainable Ocean Initiative at the World Resources Institute.

Contact: eliza.northrop@wri.org

Susan Ruffo is former Managing Director, International Initiatives, at Ocean Conservancy.

contact: sruffo@gmail.com

Gwynne Taraska is the Director of the Climate Program at Ocean Conservancy.

Contact: gtaraska@oceanconservancy.org

Lisa Schindler Murray is the Senior Manager, Policy and

Partnerships at Rare.

Contact: Ischindlermurray@rare.org

Emily Pidgeon is Vice President, Ocean Science and Innovation, Conservation International.

Contact: epidgeon@conservation.org

Emily Landis is the Coastal Wetlands Strategy Lead at The Nature Conservancy.

Contact: elandis@TNC.ORG

Elizabeth Cerny-Chipman is a Senior Policy Analyst for the Ocean Conservancy's Fish Conservation Program.

Contact: ecerny-chipman@oceanconservancy.org

Anna-Marie Laura is the Director of International Government Relations at Ocean Conservancy.

Contact: alaura@oceanconservancy.org

Dorothée Herr is the Manager, Ocean and Climate Change at the International Union for Conservation of Nature.

Contact: dorothee.herr@iucn.org

Lisa Suatoni is the Deputy Director, Oceans Division, Nature Program at the Natural Resources Defense Council.

Contact: Isuatoni@nrdc.org
Gerald Miles is the Vice President, Government Partnerships at Environmental Defense Fund.

contact: gmiles@edf.org

Tim Fitzgerald is the Senior Director for Ocean Climate Strategies at Environmental Defense Fund.

Contact: tfitzgerald@edf.org

Joshua D. McBee is a Policy and Research Associate at Climate Advisers.

Contact: mcbee@climateadvisers.org

Tamara Thomas is Director, International Ocean Policy, Conservation International.

contact: thomas@conservation.org

Sarah Cooley is the Director of Climate Science at Ocean

Conservancy.

Contact: scooley@oceanconservancy.org

Anne Merwin is the Vice President of Conservation at Ocean Conservancy.

Contact: amerwin@oceanconservancy.org

Ariane Steins-Meier is the Vice President of Global Development at Rare.

Contact: asteinsmeier@rare.org

Doug Rader is the Chief Oceans Scientist at Environmental Defense Fund.

Contact: drader@edf.org

Mario Finch is a Research Analyst II in the Global Climate Program at the World Resources Institute.

Contact: mario.finch@wri.org 


\section{ABOUT THE NDC ENHANCEMENT SERIES}

This working paper is part of a series of guidance documents developed by the World Resources Institute and the United Nations Development Programme to help government officials identify options for enhancing Nationally Determined Contributions (NDCs) in line with the Paris Agreement. Further information is available at www.wri.org/ our-work/project/stepping-2020-ndcs.

\section{ABOUT WRI}

World Resources Institute is a global research organization that turns big ideas into action at the nexus of environment, economic opportunity, and human well-being.

\section{Our Challenge}

Natural resources are at the foundation of economic opportunity and human well-being. But today, we are depleting Earth's resources at rates that are not sustainable, endangering economies and people's lives. People depend on clean water, fertile land, healthy forests, and a stable climate. Livable cities and clean energy are essential for a sustainable planet. We must address these urgent, global challenges this decade.

\section{Our Vision}

We envision an equitable and prosperous planet driven by the wise management of natural resources. We aspire to create a world where the actions of government, business, and communities combine to eliminate poverty and sustain the natural environment for all people.

\section{Our Approach}

COUNT IT

We start with data. We conduct independent research and draw on the latest technology to develop new insights and recommendations. Our rigorous analysis identifies risks, unveils opportunities, and informs smart strategies. We focus our efforts on influential and emerging economies where the future of sustainability will be determined

\section{CHANGE IT}

We use our research to influence government policies, business strategies, and civil society action. We test projects with communities, companies, and government agencies to build a strong evidence base. Then, we work with partners to deliver change on the ground that alleviates poverty and strengthens society. We hold ourselves accountable to ensure our outcomes will be bold and enduring.

\section{SCALE IT}

We don't think small. Once tested, we work with partners to adopt and expand our efforts regionally and globally. We engage with decisionmakers to carry out our ideas and elevate our impact. We measure success through government and business actions that improve people's lives and sustain a healthy environment. 